\title{
Effect of Organic Complexants on the Mobility of Nickel and Cobalt in Soils: Status Report
}

\author{
J. L. Swanson
}

September 1982

Prepared for the U.S. Department of Energy under Contract DE-AC06-76RLO 1830

Pacific Northwest Laboratory Operated for the U.S. Department of Energy by Battelle Memorial Institute 


\title{
DISCLAIMER
}

This report was prepared as an account of work sponsored by an agency of the United States Government. Neither the United States Government nor any agency thereof, nor any of their employees, makes any warranty, express or implied. or assumes any legal liability or responsibility for the accuracy, completeness, or usefulness of any information, apparatus, product, or process disclosed, or represents that its use would not infringe privately owned rights. Reference herein to any specific commercial product, process, or service by trade name, trademark, manufacturer, or otherwise, does not necessarily constitute or imply its endorsement, recommeridation, or favoring by the United States Government or any agency thereof. The views and opinions of authors expressed herein do not necessarily state cr reflect those of the United States Government or any agency thereof.

\author{
PACIFIC NORTHWEST I.ABORATORY \\ operated by \\ - bATTELLE \\ for the \\ UNITED STATES DEPARTMENT OF ENERGY \\ under Contract DE-AC06-76RLO 1830
}

\begin{tabular}{|c|c|}
\hline \multicolumn{2}{|c|}{$\begin{array}{c}\text { National Technical Information Service } \\
\text { United States Department of Commerce } \\
5285 \text { Port Royal Road } \\
\text { Springfield, Virginia 22751 }\end{array}$} \\
\hline \multicolumn{2}{|c|}{$\begin{array}{l}\text { NTIS Price Codes } \\
\text { Microfiche A01 }\end{array}$} \\
\hline \multicolumn{2}{|c|}{ Printed Copy } \\
\hline Pages & $\begin{array}{l}\text { Price } \\
\text { Codes }\end{array}$ \\
\hline $001-025$ & $\mathrm{~A} 02$ \\
\hline $026-050$ & A03 \\
\hline $051-075$ & A04 \\
\hline $076-100$ & A05 \\
\hline $10:-125$ & A06 \\
\hline $126-150$ & $\mathrm{~A} 07$ \\
\hline $151-175$ & $\mathrm{~A} 08$ \\
\hline $176-200$ & A09 \\
\hline $201-225$ & A010 \\
\hline $226-250$ & A011 \\
\hline $251-275$ & A012 \\
\hline $276-300$ & $\mathrm{~A} 013$ \\
\hline
\end{tabular}


EFFECT OF ORGANIC COMPLEXANTS ON THE MOBILITY OF NICKEL AND COBALT IN SOILS: STATUS REPORT

J. L. Swanson

September 1982

Prepared for the U. S. Department of Energy under Contract DE-AC06-76RLO 1830

Pacific Northwest Laboratory Richland, Washington 99352 


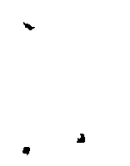

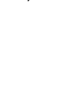

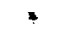

$r$

$\because$

. 


\section{SUMMARY}

Pacific Northwest Laboratory is conducting a study of the effect of organic complexing agents on the behavior of low-level waste radionuclides in soil/groundwater systems. This report contains the results of recent work with $\mathrm{Ni}$ and $\mathrm{CO}$, two elements that have radioactive isotopes that are important to low-level waste disposal.

The complexants studied were EDTA, DTPA, oxalate, and citrate. Data were obtained froin experiments using soils from both an arid site (Hanford, Washington) and a humid site (Savannah River, South Carolina). Some work with cobalt was done in the absence of air to allow the behavior of the lower oxidation state to be studied.

Important variations were observed in both the rates at which equilibrium was approached (from both the precomplexed and the presorbed directions) and the equilibrium positions themselves. The oxalate and citrate complexes are weaker and dissociate more rapidly than the EDTA and DTPA complexes. Dissociation of the EDTA and DTPA complexes occurred much more rapidly in solutions contacting Savannah River soil than in solutions contacting Hanford soil. 


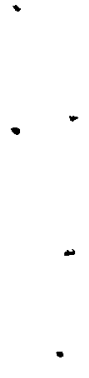

$\checkmark$
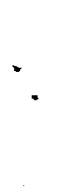


\section{CONTENTS}

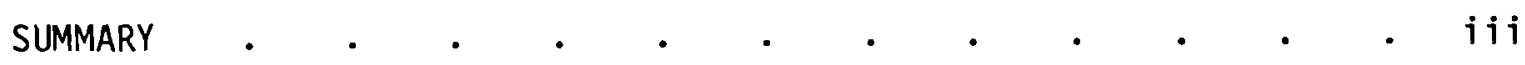

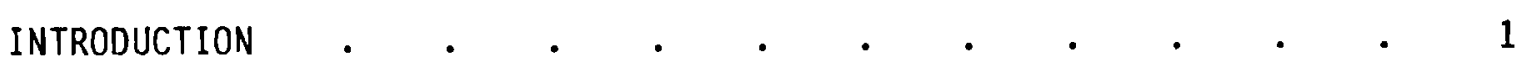

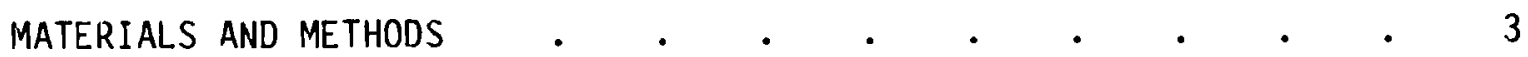

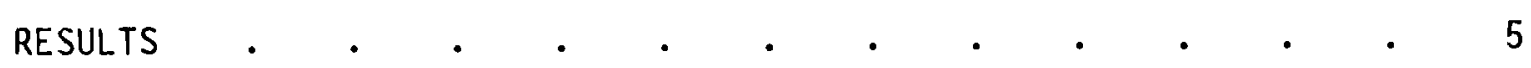

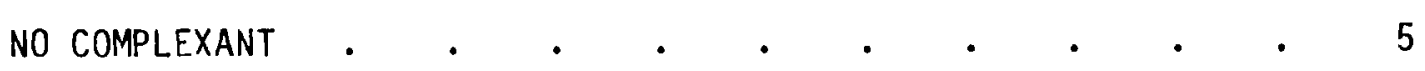

Nickel/No Complexant . $\quad . \quad$. $\quad . \quad$. $\quad . \quad$. 5

Cobalt/No Complexant . $\quad . \quad$. $\quad . \quad$. $\quad . \quad$. 7

EDTA

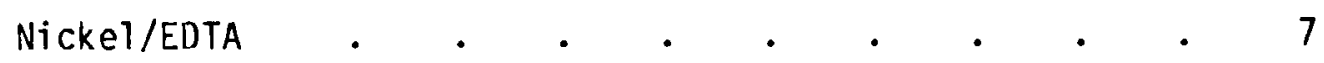

Cobalt/EDTA $\quad . \quad$. $\quad . \quad \ldots \quad$.

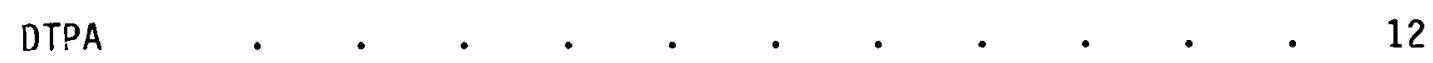

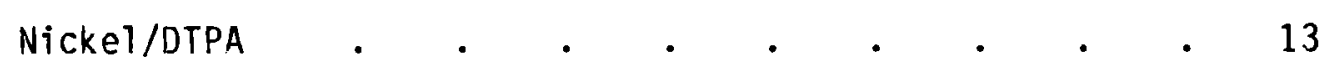

Cobalt/DTPA $\quad . \quad$. $\quad . \quad$.

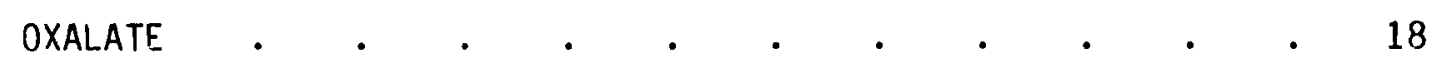

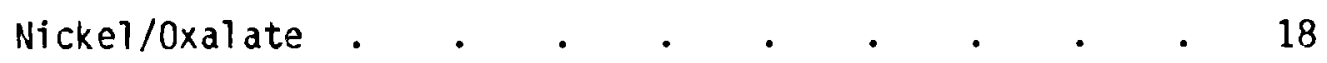

Cobalt/0xalate . $. \quad . \quad . \quad . \quad . \quad . \quad . \quad 18$

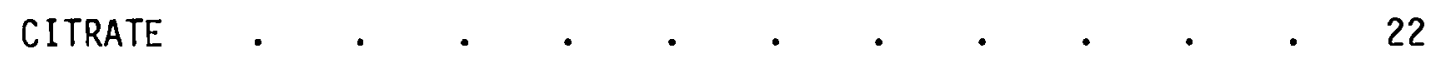

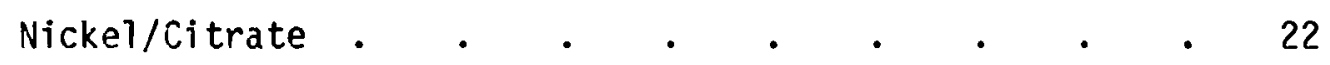

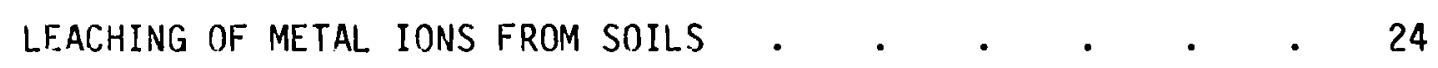

DISCUSSION

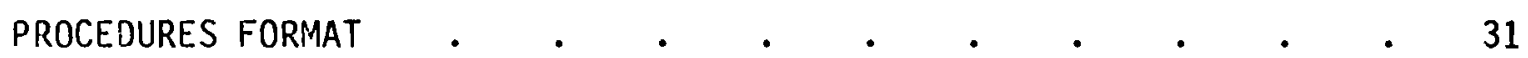

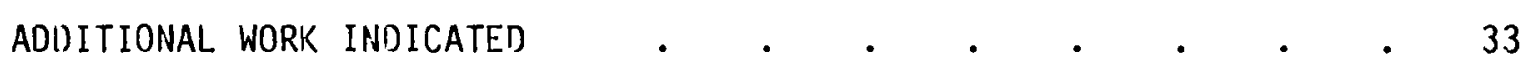

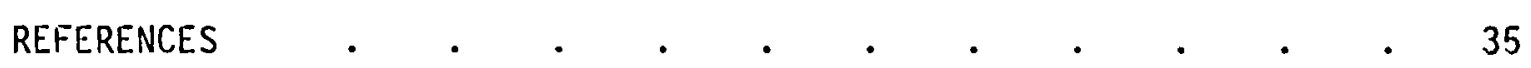

ACKNOWLEDGMENTS $\quad . \quad$. $\quad . \quad$. . . . . . . . . 37 


\section{FIGURES}

1 Rate of Sorption of Uncomplexed $\mathrm{Ni}$ by Savannah River Soil . 6

2 Rate of Desorption of $\mathrm{Ni}$ from Hanford Soil by $10^{-5} \mathrm{M}$ EDTA . 8

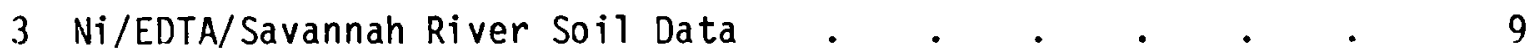

4 Co(II)/EDTA/Hanford Soil Data . . . . . . . . . 10

5 ColIII)/EDTA/Hanford Soil Data . . . . . . . . . . 11

6 Co/EDTA/Savannah River Soil Data . . . . . . . . 12

7 CO(III)/EDTA/Savannah River Soil Data . . . . . . 13

8 Rate of Dissociation of Ni/DTPA in Contact with Hanford Soil 14

9 Ni/DTPA/Hanford Soil Data $\quad$. $\quad . \quad . \quad . \quad . \quad . \quad 15$

$10 \mathrm{Ni} / \mathrm{DTPA} / \mathrm{Savannah}$ River Soil Data . . . . . . 15

11 Equilibrium Data in Ni/DTPA Savannah River Soil System . . 16

12 Co(II)/OTPA/Hanford Soil Data . . . . . . . 17

13 Co(III)/DTPA/Hanford Soil Data . . . . . . . 17

14 Equilibrium Data in Ni/Oxalate/Hanford Soil System . . . 19

$15 \mathrm{Ni} /$ xalate/Savannah River Soil Data $\quad . \quad$. $\quad . \quad$. 20

16 Effect of Air in Co/Oxalate/Hanford Soil System . . . 21

17 Equilibrium Data in Co(II)/0xalate/Hanford Soil System . . 21

$18 \mathrm{Ni} / \mathrm{Citrate} /$ Hanford Soil Data $\quad$. . . . . . . 22

$19 \mathrm{Ni}$ /Citrate/Savannah River Soil Data . . . . . 23

20 Suminary of Equilibrium Data . . . . . . . . . 26 


\section{TABLES}

A.1 Sorption of $\mathrm{Ni}$ by Hanford So il in the Absence of Complexants A.1

A.2 Sorption of $\mathrm{Ni}$ by Savannah River Soil in the Absence

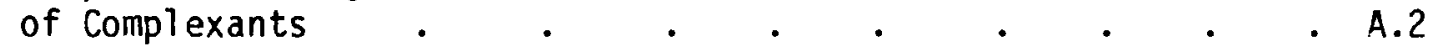

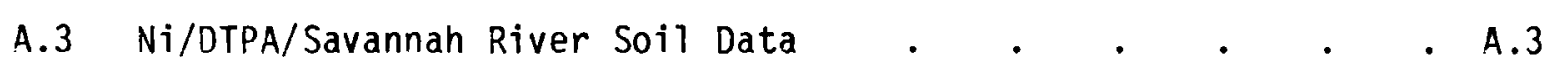

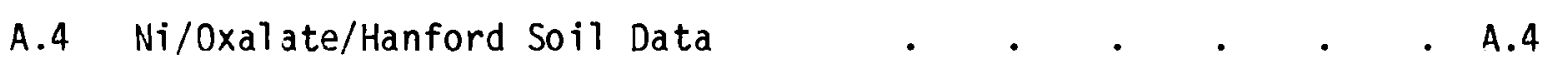

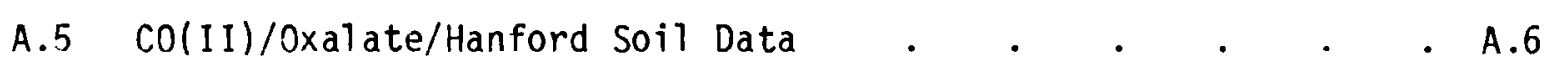

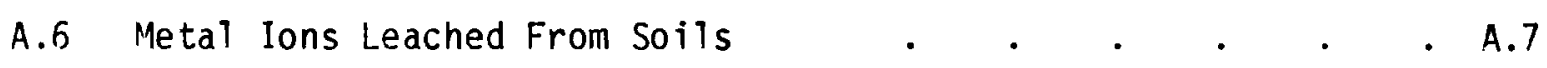


- 


\section{INTRODUCTION}

This report is an update on the status of a program at Pacific Northwest Laboratory (PNL) to develop and employ standard procedures for evaluating how and to what extent organic complexants affect the mobility of low-level waste radionuclides in soils. Previous results of this program were reported by Swanson (1981). This study showed that while the the sorption of Cs or Sr by Hanford soil was essentially unaffected by the presence of organic complexing agents, the sorption of $\mathrm{Ni}$ or Co was strongly affected. It was noted that kinetic effects were very important in the $\mathrm{Ni}$ and Co cases; the long-term behavior of these elements in Hanford soil systems varied widely, depending on whether the elements had been precomplexed before they were exposed to the soil.

This report describes results of subsequent complexant tests with $\mathrm{Ni}$ and Co, elements that have radioactive isotopes that are present in 1 arge quantities in low-level wastes. The program has been expanded to include other organic complexants commonly used in the nuclear industry and thus likely to be present in low-level wastes, and another soil that came from the Savannah River site. Very important differences in hoth the kinetic and the thermodynamic effects of organic complexants on radionuclide behavior in soil systems were observed between complexants and between soils. This report describes the status of the work through July 1982. 
$-$ 


\section{MATERIALS AND METHODS}

The radionuclide distribution between solution and soil phases was measured at rooin temperature in batch-type contacts containing different amounts of organic complexing agents. These distributions were measured by radioactive counting techniques. The soil-to-solution ratio in these contacts was about $0.033 \mathrm{~g} / \mathrm{mL}$ unless otherwise stated. For a further discussion of materials and methods see Swanson's previous work (1981).

As before, results are expressed as percent of the initial radionuclide concentration remaining in solution and/or as the apparent Kd value. The apparent $K d$ value for an element is defined as the quantity of element per gram of soil divided by the quantity of element per milliliter of solution. (The term "apparent $K d$ " is used rather than merely "Kd" because a true Kd signifies a reversible sorption equilibrium position, which is not always obtained.)

In addition to the complexants used previously ( $\mathrm{Na}_{2}$ EDTA AND DTPA), measurements were made this year in the presence of oxalate and citrate. Solutions of these complexants were prepared by dissolving the ammonium salts in water.

The study was also expanded to include soil from a burial site at the Savannah River Plant, in addition to that from the Hanford Plant. A 150- to $500-\mu \mathrm{m}-\mathrm{size}$ fraction of the dry-sieved soils was used in most cases.

Some measurements in cobalt systems were made in an inert atmosphere chamber to eliminate oxidation of Co(II) to Co(III) by air.

The solution samples were filtered before counting to assure that the measured concentrations truly represented soluble species. In addition to the ultrafiltration membrane cones (made from an inert, non-ionic polymer) with a 2-nm pore size, filter disks of different materials were also used. This was done primarily in measurements in the absence of complexing agents, where some radionuclides appeared to be retained by the membrane cones by a process such as sorption rather than by retention of solid particles. One type of filter disk used was made of polycarbonate material, and the other of cellulose ester material. The polycarbonate material sorbed little, if any, of the uncomplexed soluble species. In the presence of the organic complexing 
agents, sorption of soluble species by the filter media was not observed with any of the filters and the membrane cones were used for convenience.

In a few experiments, the concentrations of metal ions leached from soils into complexant solutions were determined. These measurements were made by emission spectroscopy using an inductively coupled plasma (ICP) for excitation.

Results this year have emphasized the importance of approaching equilibrium from both the precomplexed and the presorbed directions. This technique has uncovered some apparently anomalous behavior that might otherwise have gone unnoticed, since it would not have been detected by the "second contact" test of equilibrium that has provided an independent test.

In approaching equilibrium from the precomplexed direction, the element of interest is complexed in solution before it it exposed to the soil, which then sorbs a portion of the element. To approach equilibrium from the presorbed direction, the element is first sorbed from solution onto the soil, and complexant is than added to the soil-solution mixture so that a portion of the element is desorbed from the soil and re-enters the solution. At equilibriun the portion of the element in solution should be the same in the two cases, under a given set of conditions. 
RESULTS

Experimental results obtained this year for $\mathrm{Ni}$ and $\mathrm{Co}$ will be presented here. Results include those without complexants as well as those with EDTA, DTPA, oxalate, and citrate complexants. Many of the element/complexant systems were tested with Savannah River soil as well as Hanford soil. Data are also presented on the concentrations of metal ions leached from the soil by the complexant solutions.

NO COMPLEXANT

Element distribution values in the absence of complexants are necessary as a baseline from which the effects of such complexants can be measured. Values reported last year (Swanson 1981) are now thought to have been unreasonably high because the filters used evidently removed some soluble species from solution by a sorption process. One indication of this was that when successive portions of a solution were passed through the same membrane filter cone, the element concentration found in successive filtrate portions gradually increased. Another indication was that when portions of a solution were passed through filters of different materials (with different pore sizes), the amount of element retained by the filter varied widely (but not in proportion to pore size). These observations were made with both $\mathrm{Ni}$ and $\mathrm{Co}$ in the absence of complexants.

To solve this problem, a type of disk filter made of polycarbonate material and available in a variety of pore sizes was used in the absence of complexants. Nearly all $(>80 \%)$ of the elements contained in "pure" solutions passed through such filters (whether 0.015 or $0.1 \mu \mathrm{m}$-pore size), and there was no change when successive portions were passed through the same filter.

\section{Nickel/No Complexant}

When Ni solutions ranging froin $2 \times 10^{-7}$ to $5 \times 10^{-9} \mathrm{M}$ were contacted with Hanford soil at a soil-to-solution ratio of $0.033 \mathrm{~g} / \mathrm{mL}$ for time periods of 2 to 19 days, about $2.2 \%$ of the $\mathrm{Ni}$ remained in solution (giving an apparent Kd value of $1300 \mathrm{~mL} / \mathrm{g}$ ), with the $\mathrm{pH}$ being about 9. Such constancy with varying $\mathrm{Ni}$ concentration suggests that this apparent $\mathrm{Kd}$ value might truly represent a reversible sorption equilibrium. However, higher apparent $k d$ values were 
obtained at lower soil-to-solution ratios, which would not be the case for a simple, reversible sorption equilibrium case. The reason for the discrepancy is not known. Data are contained in Table A.1 in the Appendix.

Another experiment with Hanford soil was done, this time at a lower pH. The apparent $K d$ value was about tenfold lower at a $\mathrm{pH}$ value of 6 than at a value of about 9 .

With Savannah River soil, Ni was not sorbed as rapidly as it was with Hanford soil. Figure 1 contains data illustrating this slow sorption, and more complete data are contained in Table A.2 of the Appendix. Good agreement was obtained between analyses performed on the solution after only centrifugation and after filtration through a polycarbonate filter; this provides additional evidence that the polycarbonate filters did not remove any $\mathrm{Ni}$ by a sorption process. Also, as was the case with Hanford soil, initial $\mathrm{Ni}$ concentration does not seem to affect the fraction of Ni sorbed by the soil.

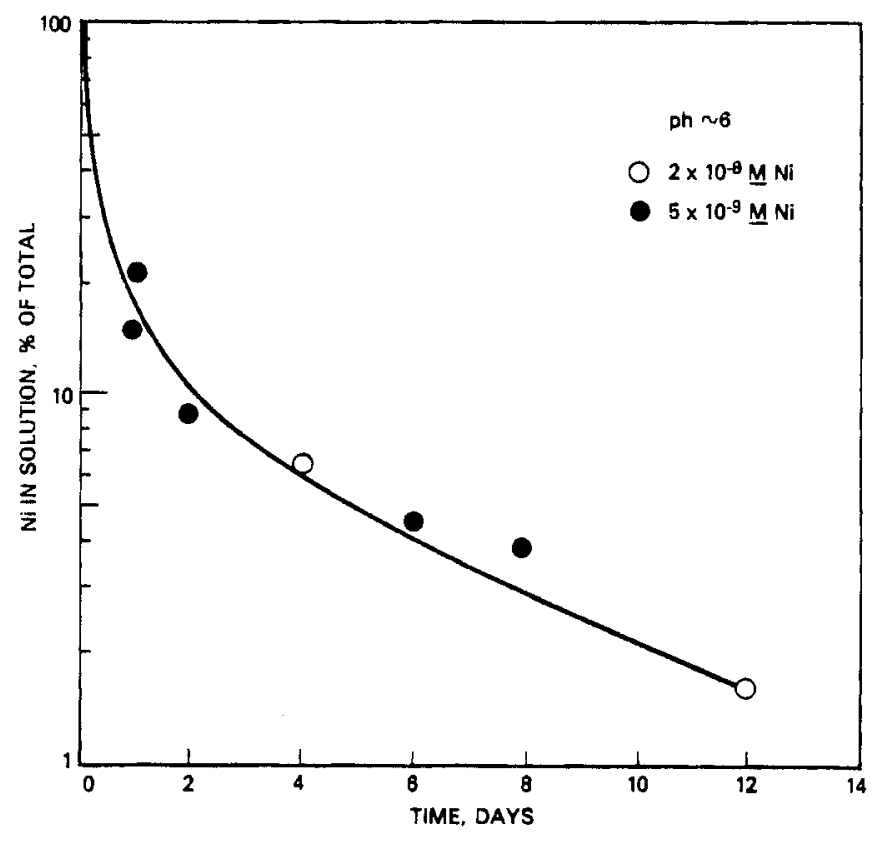

FIGURE 1. Rate of Sorption of Uncomplexed $\mathrm{Ni}$ by Savannah River Soil 
Cobalt/No Complexant

No measurements have been made of the distribution of Co(II) between soils and solutions in the absence of organic complexants. However, distribution coefficients higher than $10^{3}$ have been measured at low complexant concentrations with both Hanford and Savannah River soils. It appears to be safe to assume that $C o$ (II) distribution coefficients at least that high would result when complexants are absent.

EDTA

Ethylenediaminetetraacetic acid (EDTA) is a relatively strong complexing agent widely used as a decontaminating agent in the nuclear industry and thus will be present in untreated nuclear waste. Our earlier work (Swanson 1981) showed that kinetic effects were especially important in Hanford soil systems containing this complexant and $\mathrm{Ni}$ or Co.

\section{Nickel/EDTA}

When in contact with Hanford soil for a year, $\mathrm{Ni}$ that was precomplexed by EDTA remained completely in solution; this has been observed in eight experiments at EDTA concentrations ranging from $1 \times 10^{-7}$ to $3.5 \times 10^{-9} \mathrm{M}$ and soil-to-solution ratios of 0.033 to $0.010 \mathrm{~g} / \mathrm{mL}$. Thus, $\mathrm{Ni}$ that has been coinplexed by EITA would be expected to migrate through Hanford soil at the same rate as ground water.

When $\mathrm{Ni}$ was sorbed onto Hanford soil before EDTA was added to the system, the $\mathrm{Ni}$ tended to dissolve, but only very slowly (see Figure 2). After 6 months only about half of the $N i$ had dissolved into $1 \times 10^{-5}$ M EDTA, but, with precomplexed $\mathrm{Ni}$, all of the $\mathrm{Ni}$ remained in solution even though the EDTA concentration was much lower. Little additional Ni dissolved in another 9 months, but it is not known whether this was because of the attainment of an equilibrium position. 


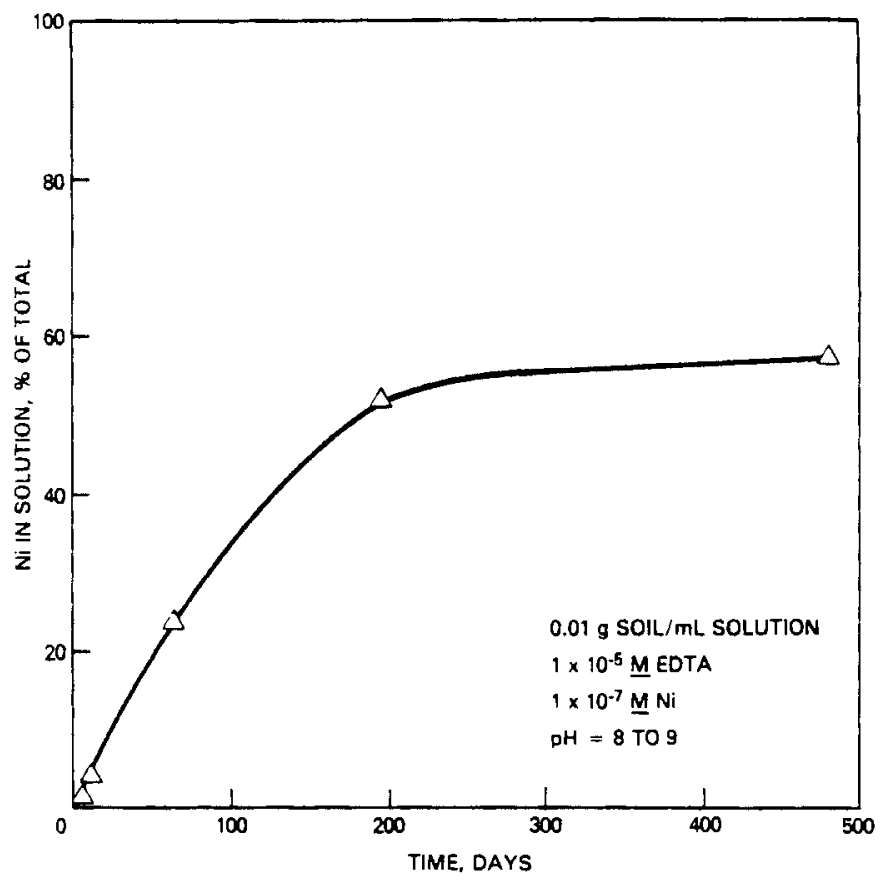

FIGURE 2. Rate of Desorption of Ni from Hanford Soil by $10^{-5}$ M EDTA

Witn Savannah River soil, however, an apparent equilibrium position was attained within several weeks. Figure 3 contains data in which equilibriun was approached from both the precomplexed direction, where $\mathrm{Ni}$ was complexed by EDTA before being exposed to the soil, and the presorbed direction, where Ni was sorbed by the soil before EDTA was added. When a 2-day sorption period was allowed before the EDTA was added, the fraction of $\mathrm{Ni}$ found in solution reached agreement with that found from the sorption direction within 23 days, indicating that an equilibrium position had been reached. When a 33-day period was allowed before the EDTA was added, the equilibrium position was approached more slowly. This apparent dependence of the rate of desorption on the length of the sorption period may warrant additional investigation.

The relatively rapid approach to equilibrium with $\mathrm{Ni} /$ EDTA solutions in contact with Savannah River soil indicates that precomplexed $\mathrm{Ni}$ would migrate through Savannah River soil at a rate much lower than the rate of groundwater migration, in contrast to the behavior indicated for Hanford soil. This 


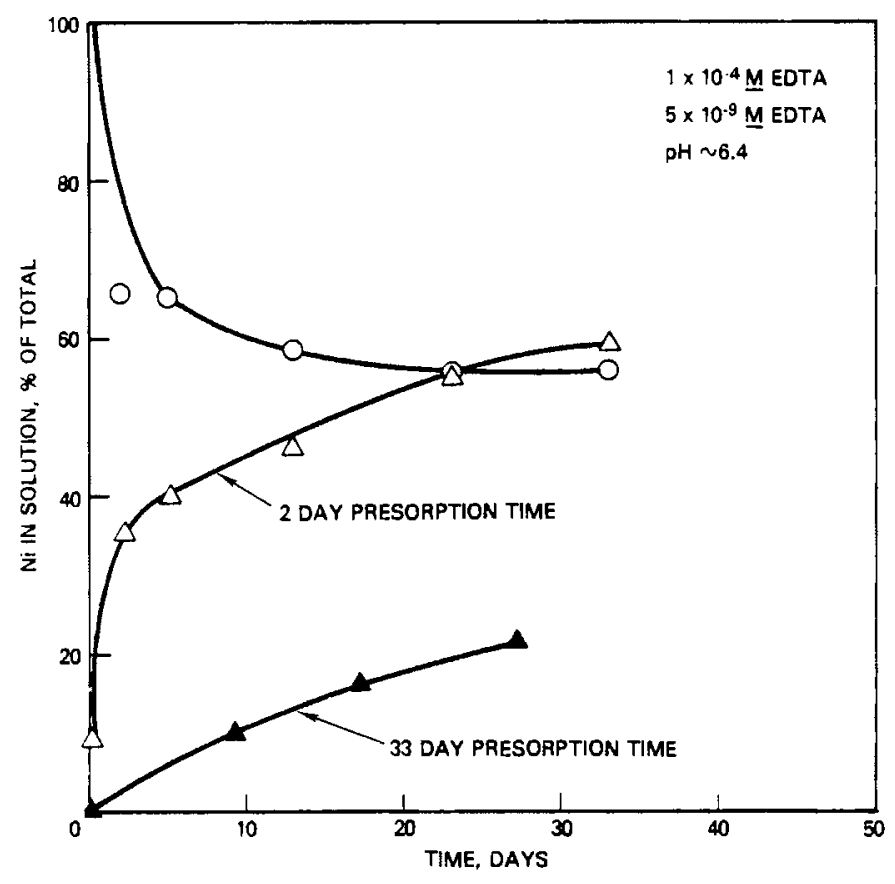

FIGURE 3. Ni/EDTA/Savannah River Soil

contrast is quite important, and the reason for this difference will be the subject of future investigations. One possible reason is solution $\mathrm{pH}$ (solutions in contact with Savannah River soil have a much lower pH than solutions in contact with Hanford soill, but this has not been proved to be the reason for the marked difference.

\section{Cobalt/EDTA}

Preliminary data from the Co(II)/EDTA system (in an argon atmosphere) with Hanford soil are shown in Figure 4. As in the corresponding Ni/EDTA systen, slow kinetics are a problem; a large difference still exists after a month between the data obtained from the precomplexed and presorbed directions. It does appear that $\mathrm{Co}_{\mathrm{O}}$ is equilibrating more rapidly than $\mathrm{Ni}$, however. 


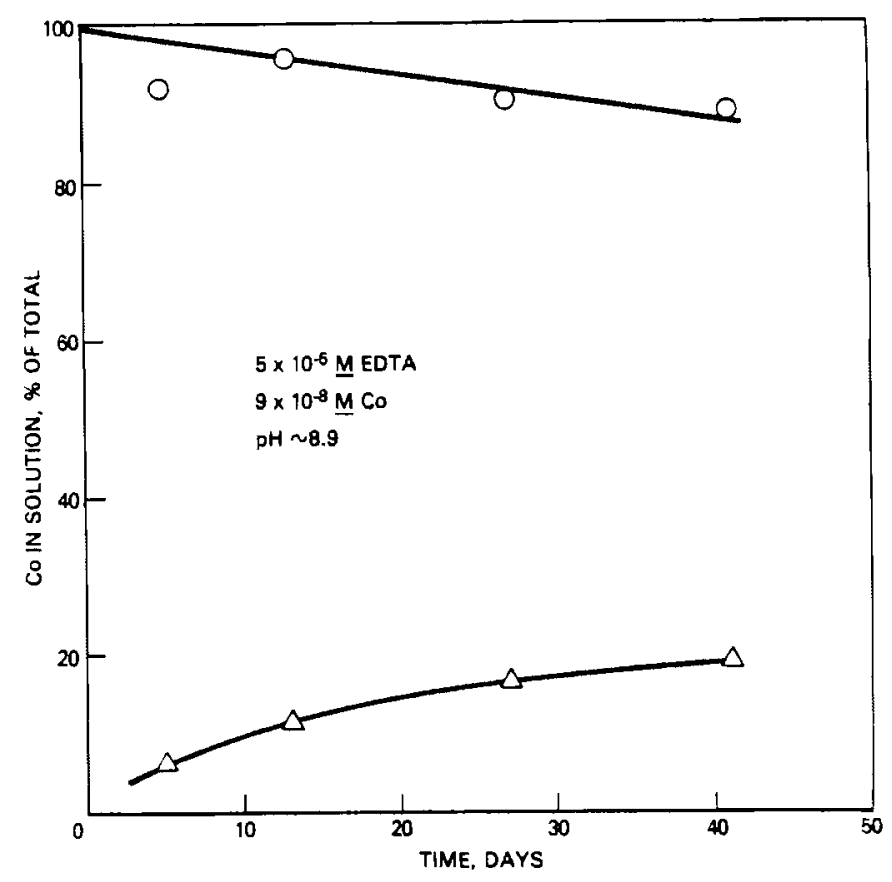

FIGURE 4. CO(II)/EDTA/Hanford Soil Data

In EDTA solutions in the presence of air, as in the earlier experiments (Swanson 1981), the Co(II) is likely oxidized to Co(III), which forms more stable complexes. Some results obtained with Hanford soil in such experiments are presented in Figure 5. These results were obtained with dilutions of a stock solution containing $1 \times 10^{-5} \mathrm{M} \mathrm{CO}+2 \times 10^{-5} \mathrm{M}$ EDTA, with the dilutions inade just before contact with the soil. Little difference was observed in the results of using stock solution 2 days or 1 month old, but a marked difference was observed with the 11-month old stock solution. It appeared that after this period of time only a portion of the Co was still complexed; perhaps enough of the EDTA decomposed during this time that not enough remained to complex all of the Co.

The slow changes with time of soil contact indicate that the Co(III)-EDTA complex is slowly dissociating so that the uncomplexed Co can be sorbed by the soil. The rate of this dissociation appears to vary inversely with EDTA concentration. 


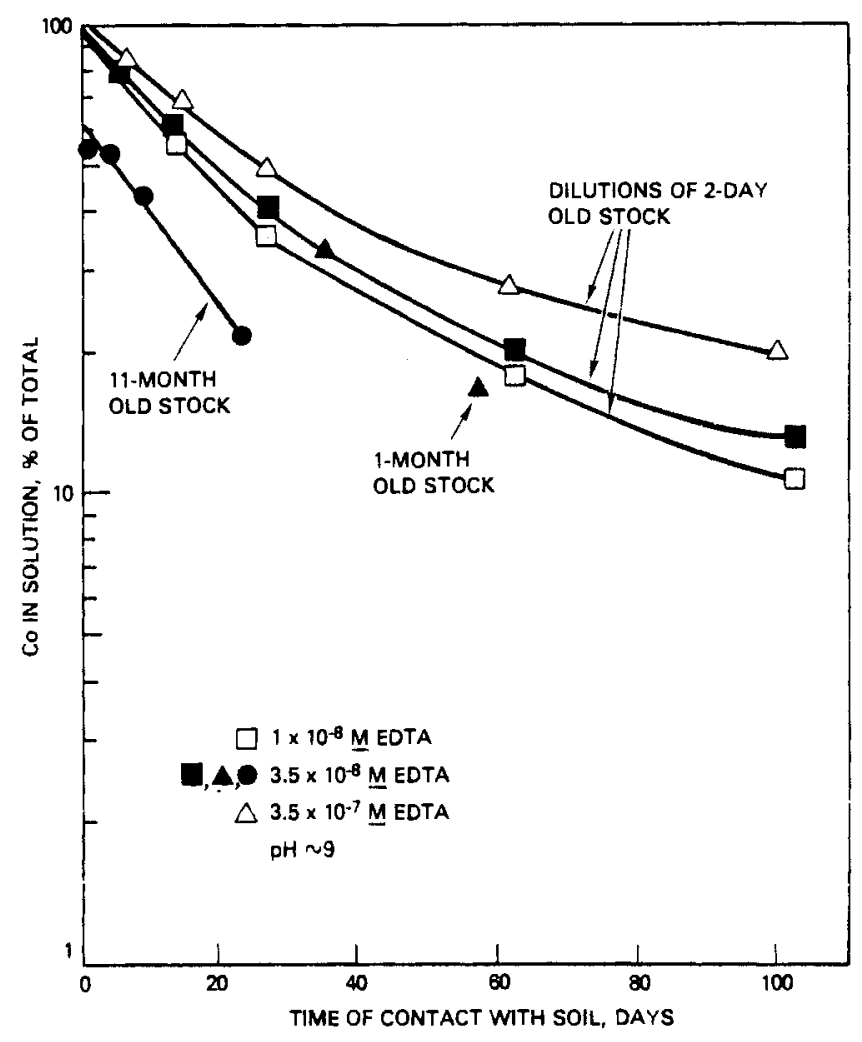

FIGURE 5. Co(III)/EDTA/Hanford Soil Data

An important conclusion from these data is that even though the reaction is slow, the CO(III)-EDTA complex does dissociate in Hanford soil systems. Therefore, the EDTA-complexed Co would not be expected to travel through Hanford soil at the same rate as water if the water flow rate is low enough to allow time for the dissociation to occur. This expectation has been substantiated by extended field studies (Kirkham and Jones 1982); in this work very little (if any) inovement of EDTA-complexed Co was observed over a 3-year period in lysimeter experiments using Hanford soil and water fluxes typical of those encountered at the Hanford site.

Data obtained with Savannah River soil in the Co(II)/EDTA system are presented in Figure 6 . With $5 \times 10^{-5}$ M EDTA, approaching equilibrium from both the precomplexed and the presorbed directions gave the same concentration of $\mathrm{Co}$ in solution after about 2 weeks, but the concentrations then diverged 


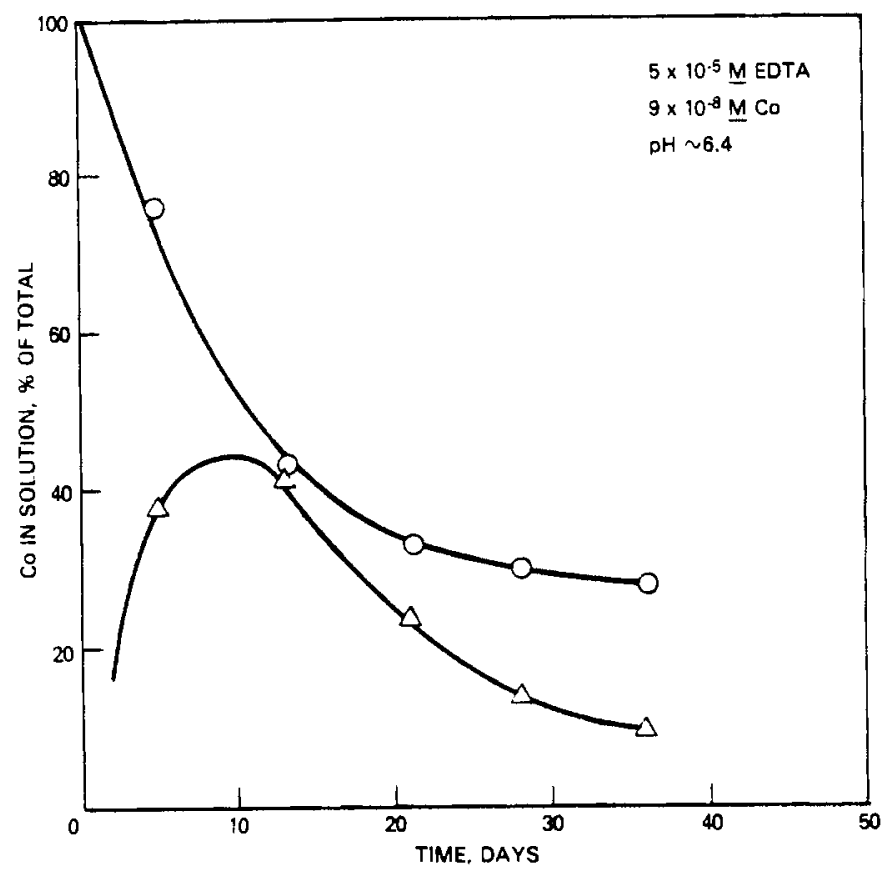

FIGURE 6. Co/EDTA/Savannah River Soil Data

again. This increase and subsequent decrease in co concentration has also been observed in other systems to be covered later. It is postulated that such behavior is due to a reduction in free complexant concentration with tine. Such a reduction might occur because of complexant destruction and/or complexing by alements leached from the soil. Such behavior will be the subject of future investigations.

Preliminary results for the Co(III)/EDTA/Savannah River soil system are shown in Figure 7. As with the Co(II) case, the Co(III) concentration changes more rapidly over time with Savannah River soil than with Hanford soil. Also, an initial increase in Co concentration was followed by a decrease in one of these $\operatorname{co}($ III) presorption-type experiments.

DTPA

Diethylenetriaminepentaacetic acid (DTPA) is another complexing agent used in the nuclear industry. It is even stronger than EDTA and thus, at equilibrium, it should take less DTPA than EDTA to affect the behavior of 


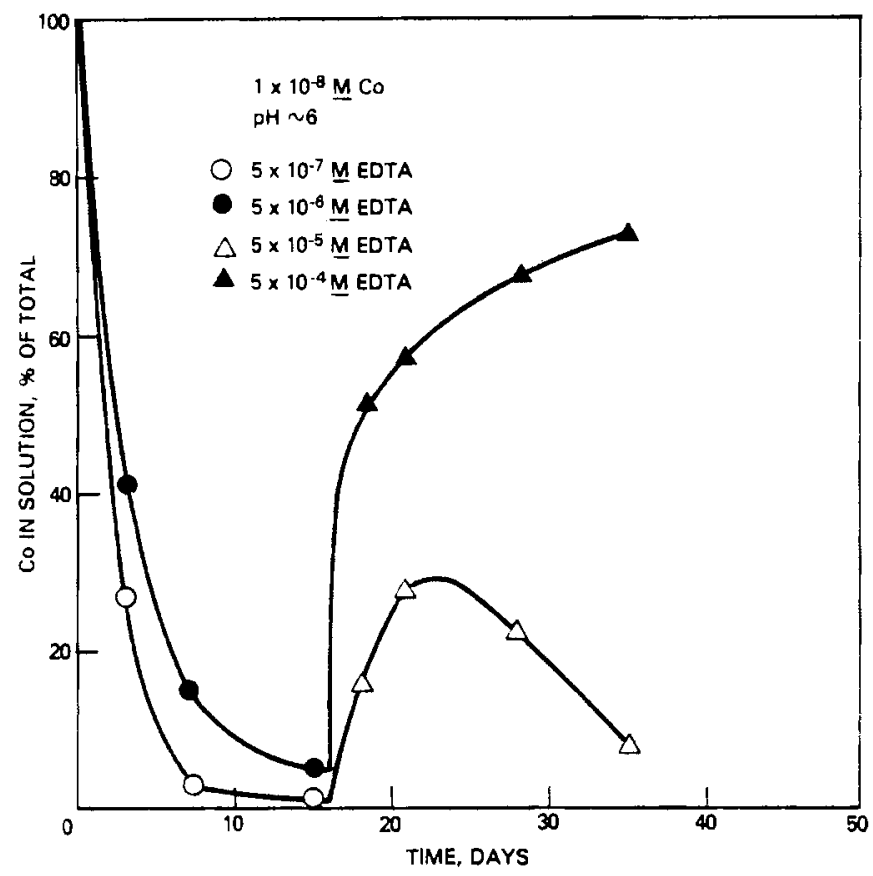

FIGURE 7. Co(III)/EDTA/Savannah River Soil

radionuclides in soils. Earlier work (Swanson 1981) showed that kinetic effects were also quite important in Hanford soil systems containing this complexant and $\mathrm{Ni}$ or $\mathrm{Co}$, al though not to the extent that they are with EDTA.

\section{Nickel/DTPA}

Nickel that was precomplexed by DTPA and then contacted with Hanford soil at IOW DTPA concentrations is gradually being sorbed by the soil. The reaction roughly followed first-order kinetics for nearly a year, as shown by the data plotted in Figure 8 . It should be recalled that similar experiments involving EDTA gave no decrease in $\mathrm{Ni}$ concentration over this tine period, demonstrating that the $\mathrm{Ni}-D T P A$ complex dissociates more rapidly than the $\mathrm{Ni}$ EDTA complex. In these experiments the soil-to-solution ratio had little effect on the concentration of $\mathrm{Ni}$ in solution in the short term, as would be expected for the situation where the complex dissociation rate is the controlling factor. 


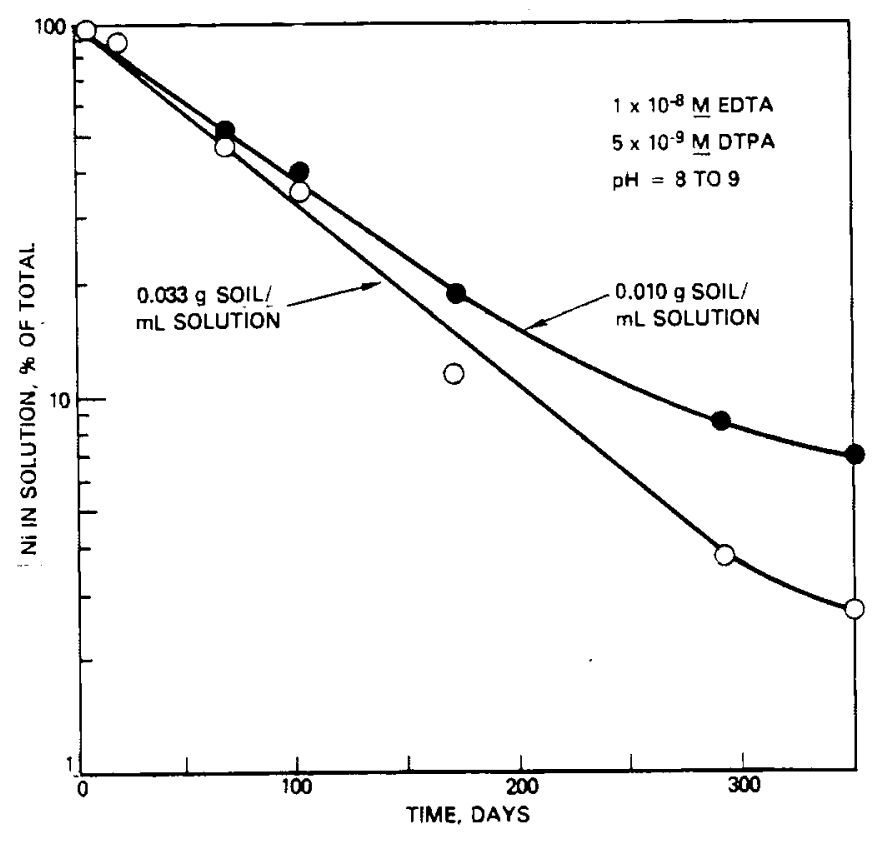

FIGURE 8. Rate of Dissociation of Ni-DTPA in Contact with Hanford Soil

It is possible that all of the Ni will eventually be sorbed by the soil in the experiments shown in Figure 8. Some experiments have thus been started at higher DTPA concentrations. These experiments include sets involving both precomplexed and presorbed $\mathrm{Ni}$ at given OTPA concentrations; the equilibrium condition at a given DTPA concentration must lie within the range of these two measurements. Results obtained thus far are presented in Figure 9. At the relatively short time intervals involved, the range is very 1 arge.

As in the Ni/EDTA system, the Ni/OTPA system reached equilibrium much more rapidly with Savannah River soil than with Hanford soil (see Table A.3). Figure 10 contains data showing typical changes in $N i$ concentration with tine, and Figure 11 is a plot of the steady-state apparent kd values as a function of added DTPA concentration. With $0.033 \mathrm{~g} \mathrm{soil/mL} \mathrm{solution,} \mathrm{the}$ apparent $K d$ value was about $10 \mathrm{~mL} / \mathrm{g}$ at an added DTPA concentration of about 1 $\times 10^{-3}$ M. The $\mathrm{Kd}$ value was decreasing approximately tenfold for each tenfold 


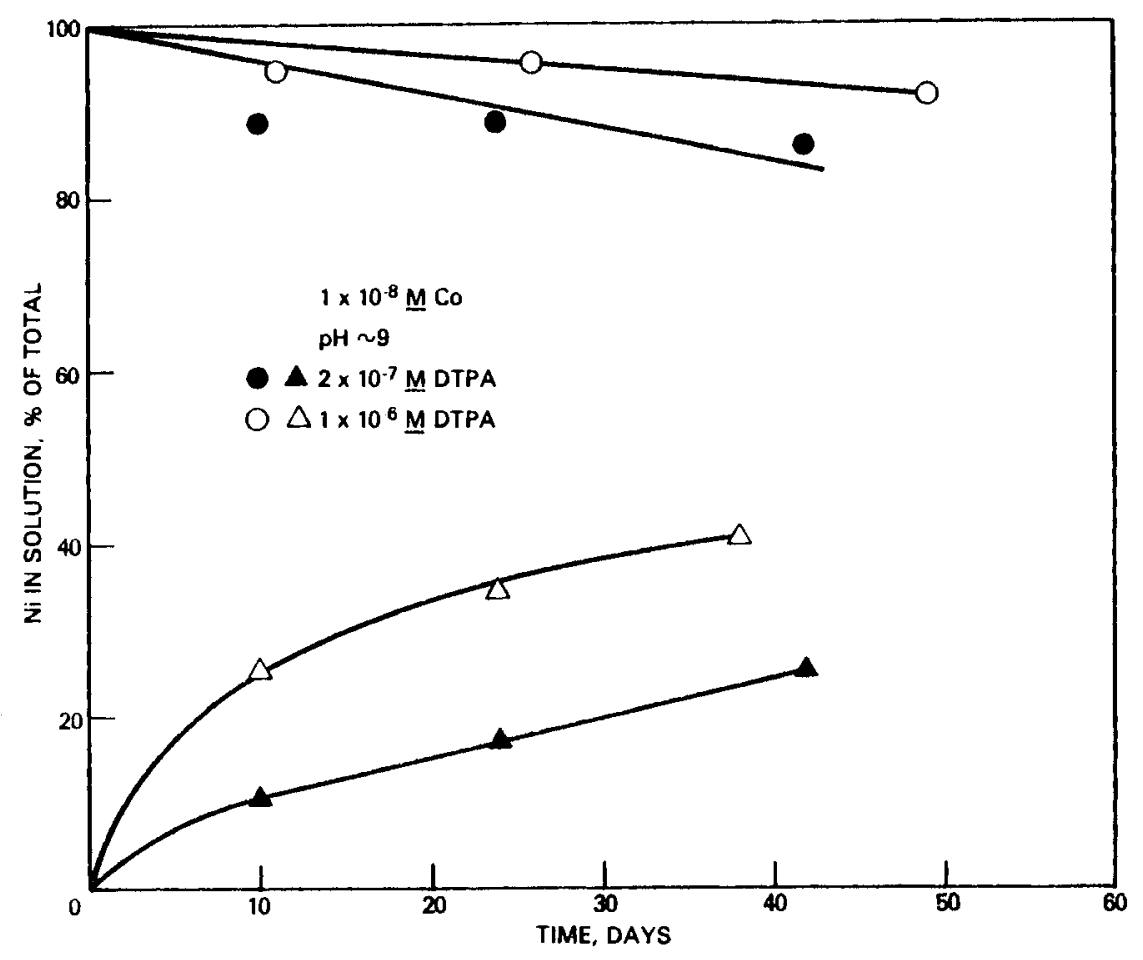

FIGURE 9. Ni/DTPA/Hanford Soil Data

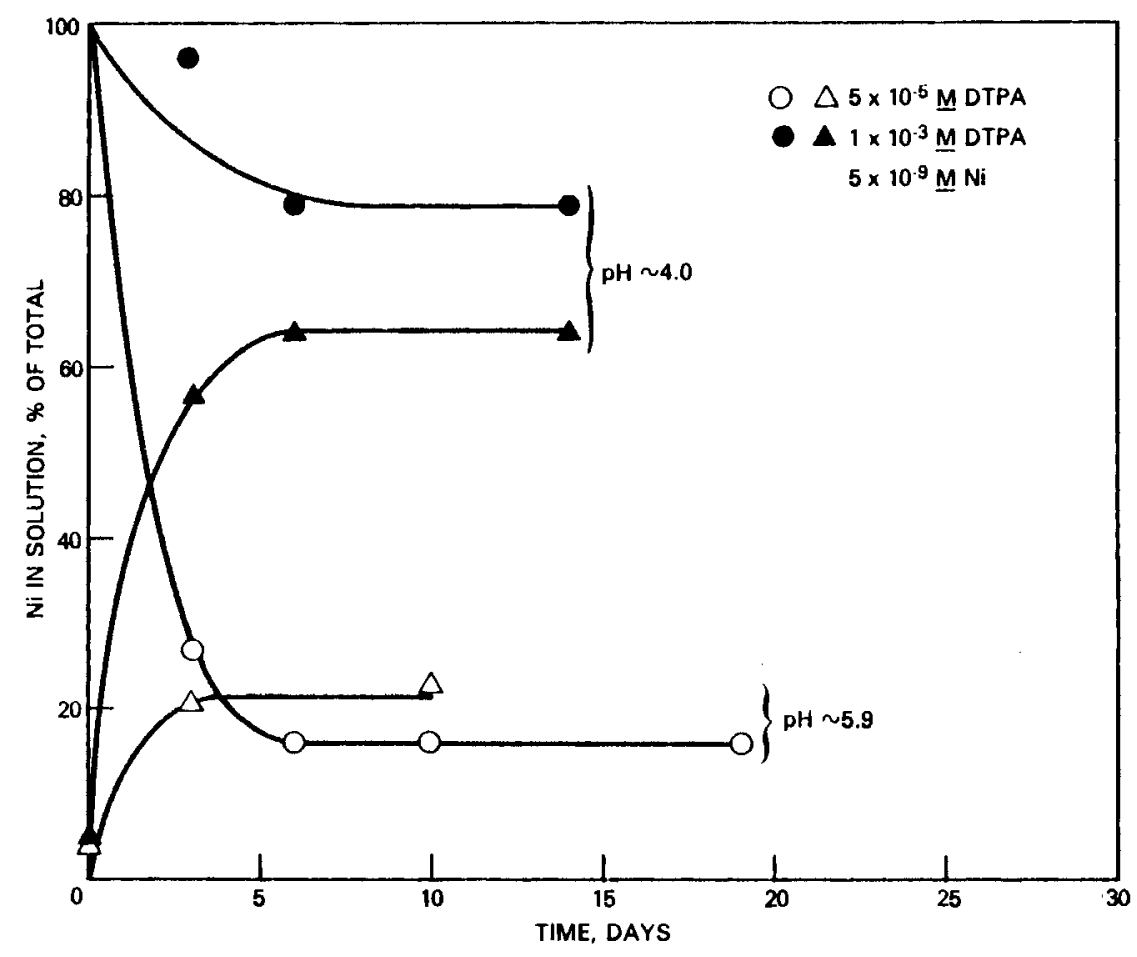

FIGURE 10. Ni/DTPA/Savannah River Soil Data 


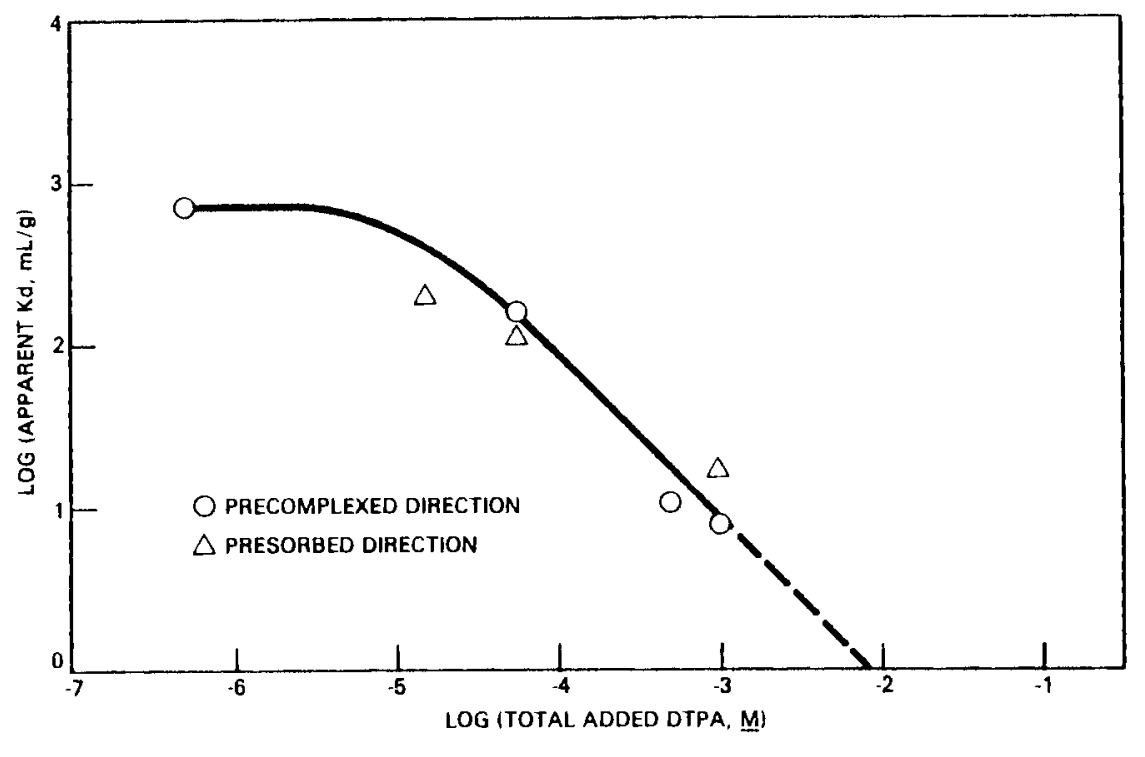

FIGURE 11. Equilibrium Data in Ni/DTPA

Savannah River Soil System

increase in DTPA concentration, so that the kd value would be expected to be 1 at about $1 \times 10^{-2} \mathrm{M}$ OTPA. Additional experiments should be done in this system to neasure the effects (if any) of $\mathrm{Ni}$ concentration and soil-tosolution ratio.

Cobalt/DTPA

Preliminary results of tests in the Co(II)/DTPA/Hanford soil system are shown in Figure 12. As in the corresponding $\mathrm{Ni}$ case, the approach to equilibrium is slow. One of the desorption experiments also gave an initial increase in co concentration followed by a decrease, as has been observed in some other systems.

In earlier experiments in the presence of air, results were obtained that appear to reflect the oxidation of Co(II) to Co(III). A stock solution containing $1 \times 10^{-5} M \mathrm{M} O+2 \times 10^{-5} \mathrm{M}$ DTPA was prepared, and portions were diluted after different time intervals for contact with Hanford soil, in analogous inanner to some of the Co/EDTA experiments described earlier. With Co/DTPA, the variation in Co concentration with the time of contact with soil was a function of the age of the stock solution at the time it was diluted for contact with soil, as shown by Figure 13. Much less Co was sorbed from a 


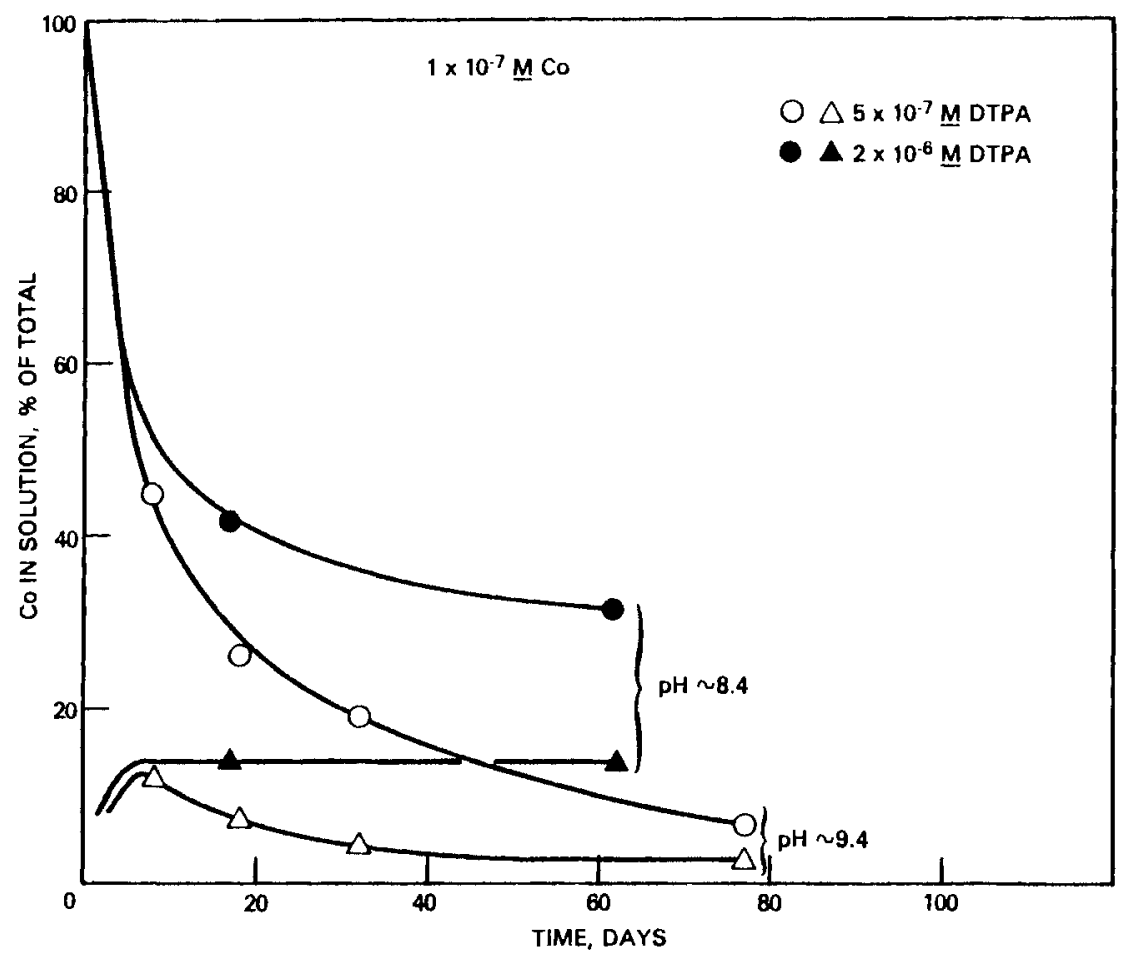

FIGURE 12. Co(II)/DTPA/Hanford Soil Data

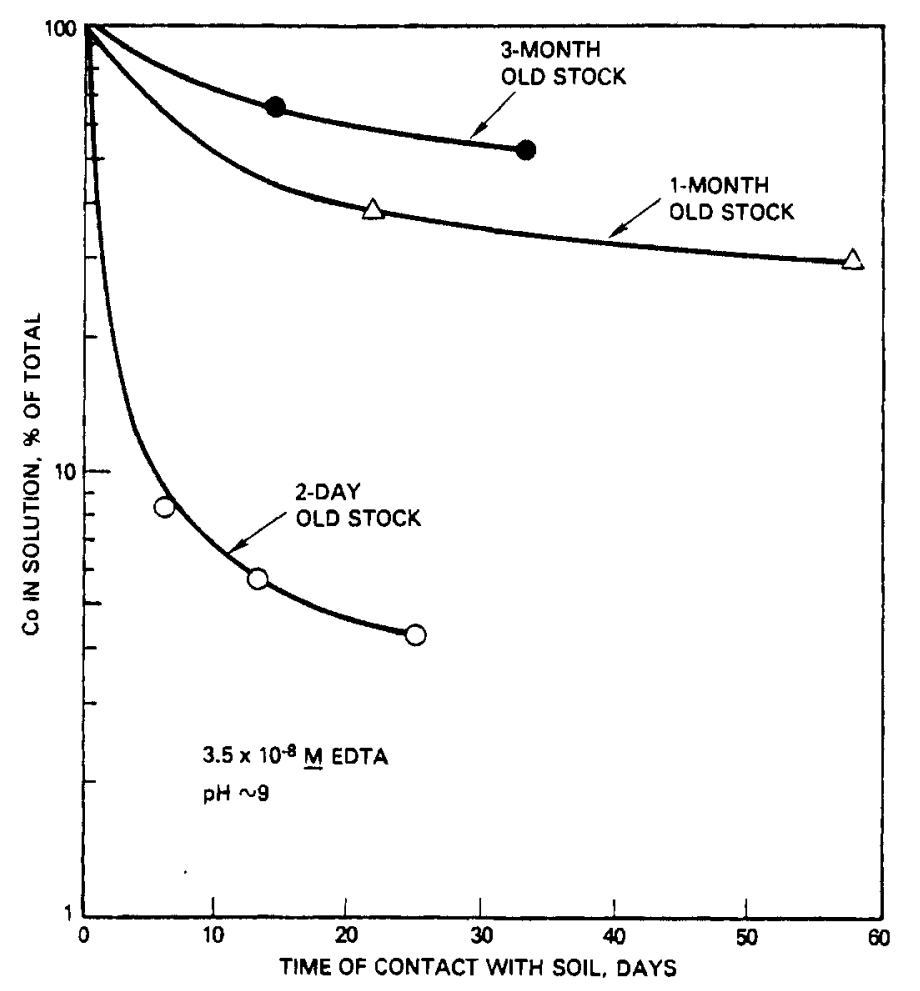

FIGURE 13. Co(III)/DTPA Hanford Soil Data 
dilution of the aged stock solution than from a dilution of the fresh stock solution, presumably because of oxidation of Co(II) to Co(III) in the stock solution as it stands.

No data have yet been obtained with Savannah River soil in the Co/DTPA system.

OXALATE

Oxalate is another organic complexing agent widely used as a decontaminating agent and thus will be present in untreated nuclear waste. Dxalate is known to form much weaker complexes with metal ions than does EDTA or DTPA.

\section{Nickel/Oxalate}

This systen reached equilibrium with Hanford soil quite rapidly (within a few days), in contrast to the behavior observed with EDTA and DTPA. Many experiments were done here to vary the concentrations of nickel and oxalate, the solution-to-soil ratio, the soil particle size, and the direction of approach to equilibrium. Data from experiments using ammonium oxalate are suminarized in Table A.4.

Typical equilibrium data for the $\mathrm{Ni} /\left(\mathrm{NH}_{4}\right)_{2} \mathrm{Ox} /$ Hanford soil system are plotted in Figure 14. There appears to be no great effect of any of the investigated variables except for the complexant concentration. The dependence of the apparent $K d$ value on the added oxalate concentration is greater than the dependence observed in the Ni/DTPA/Savannah River soil system discussed previously or in the Eu/EDTA/Hanford soil system studied earlier (Swanson 1991). Whereas the apparent Kd values in those systems decreased approximately tenfold for a tenfold increase in complexant concentration, in the $\mathrm{Ni} /\left(\mathrm{NH}_{4}\right)_{2} \mathrm{Ox} /$ Hanford soil system, the apparent $\mathrm{Kd}$ values decreased approximately 100-fold for a tenfold increase in complexant concentration. Extrapolation of these data indicates that the $\mathrm{Kd}$ value would be expected to be 1 at about 0.08 M ammonium oxalate. 


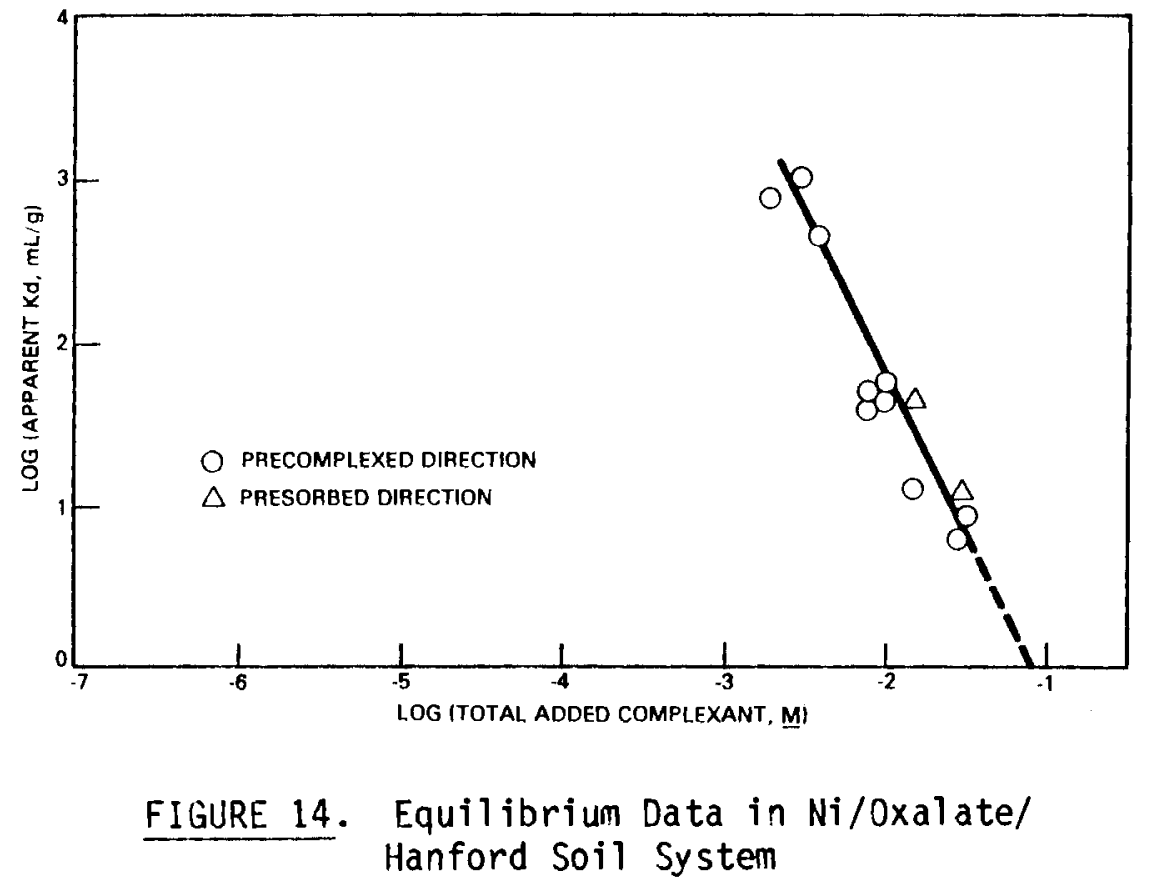

Before these experiments with ammonium oxalate were done, a few tests were inade with oxalic acid. The results were similar to those with ammonium oxalate except that lower $\mathrm{pH}$ values were obtained with oxalic acid. For example, with $0.01 \mathrm{M}$ oxalic acid and a soil-to-solution ratio of $0.033 \mathrm{~g} / \mathrm{mL}$, the $\mathrm{pH}$ was about 5 , and the apparent $K d$ was about $22 \mathrm{~mL} / \mathrm{g}$. This $\mathrm{kd}$ value is about one-third that obtained at a pH of about 9 at the same oxalate concentration (Figure 14).

Some of the preliminary results obtained with Savannah River soil in the $\mathrm{Ni} /$ oxalate system are shown in Figure 15. As was al so observed in the Ni/EDTA Savannah River soil system, the results obtained in presorption-type experiments depend on the length of time before complexant addition. Also, initial increases in $\mathrm{Ni}$ concentration were followed by decreases, as has been observed in several other systems. Results of precomplexed-type experiments at other oxalate concentrations indicate that the apparent $k d$ depends much less strongly on the added oxalate concentratio with Savannah River soil than with Hanford soil (Figure 14). 


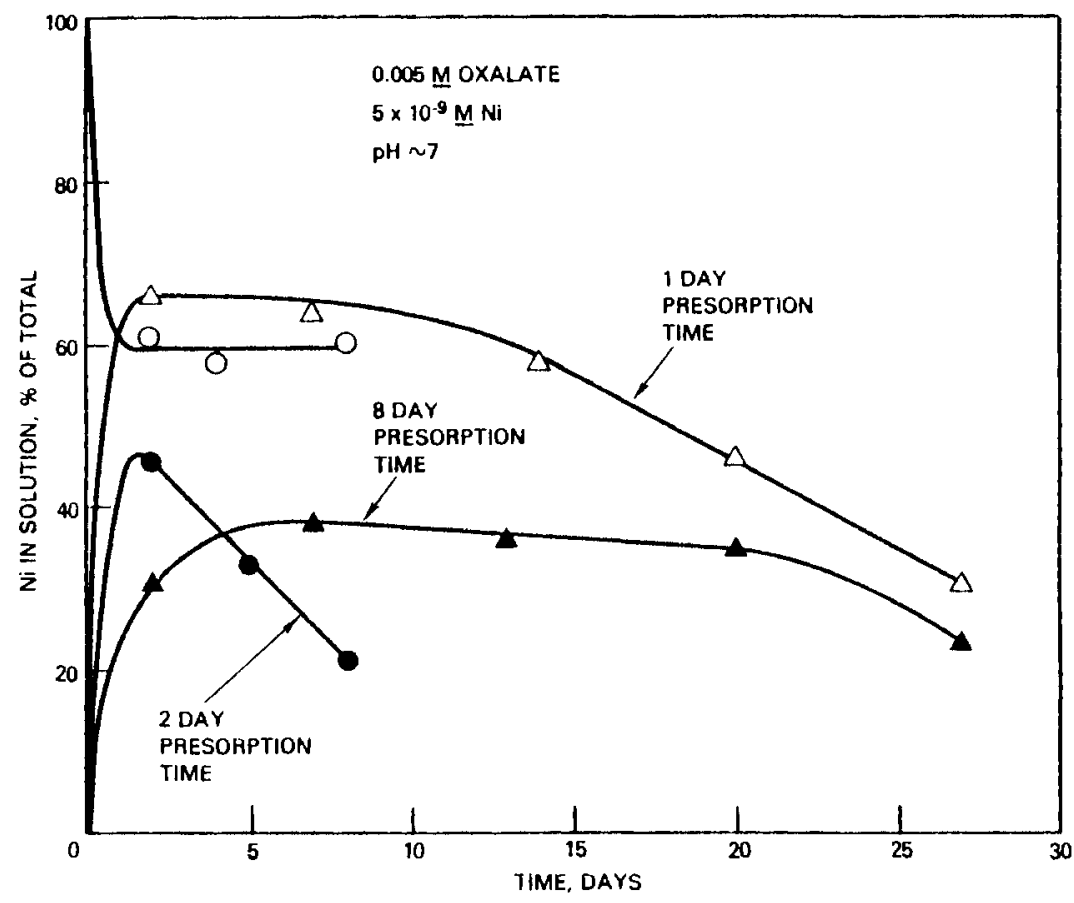

FIGURE 15. Ni/Oxalate/Savannah River Soil Data

Cobalt/0xalate

The $\mathrm{Co}(\mathrm{II}) /\left(\mathrm{NH}_{4}\right)_{2} \mathrm{Ox}$ system also reached equilibrium quite rapidly with Hanford soil. Comparison of data in this system in the presence and absence of air (Figure 16) shows the importance of excluding air. In an argon atmosphere an equilibrium position was reached rapidly, and remained stable for many days. In air, however, the apparent equilibrium position gradually shifted to give more co in solution, presumably because of oxidation to Co(III).

The data obtained in the $\mathrm{Co}(\mathrm{II}) /\left(\mathrm{NH}_{4}\right)_{2} \mathrm{Ox} /$ Hanford soil system are tabulated in Table A.5, and the apparent $K d$ values are plotted as a function of oxalate concentration in Figure 17. As in the $\mathrm{Ni} /\left(\mathrm{NH}_{4}\right)_{2} \mathrm{Ox} / \mathrm{Hanford}$ soil system, the apparent $K d$ values decreased approximately 100-fold for a tenfold increase in added oxalate concentration. Extrapolation of these data indicates that the $\mathrm{Kd}$ value would be expected to be 1 at about 0.2 ammonium oxalate. 


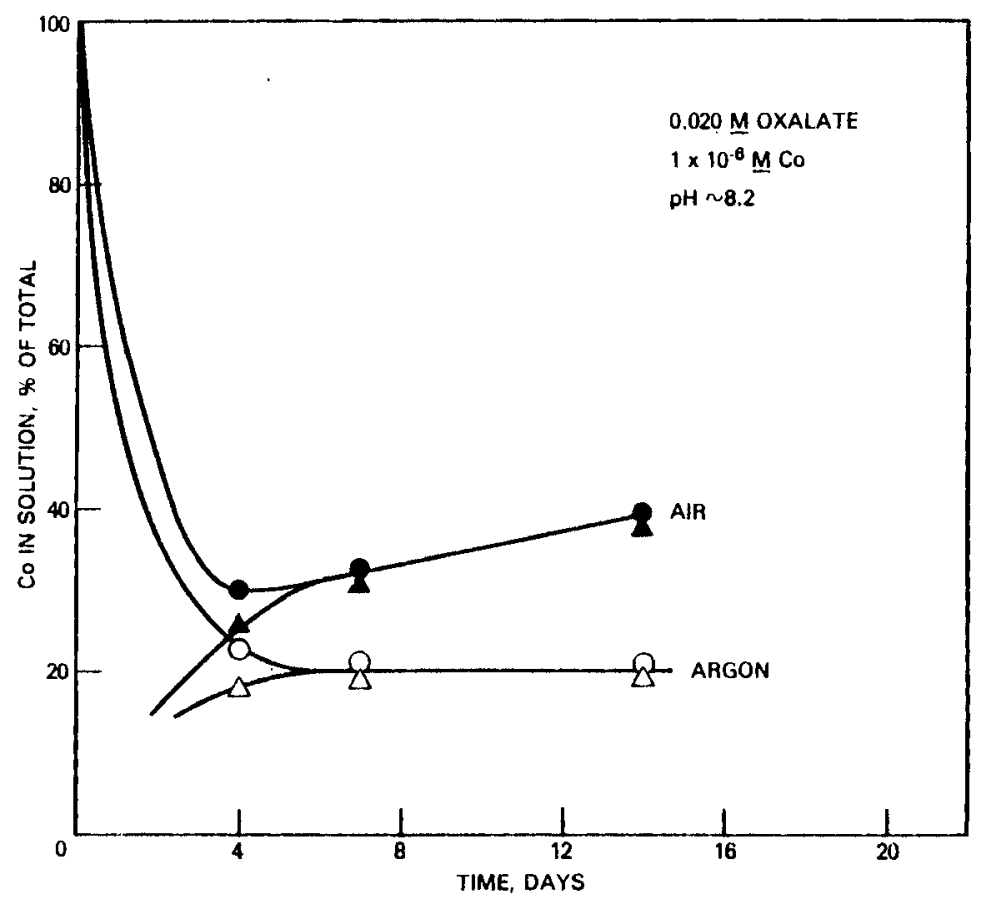

FIGURE 16. Effect of Air in Co/0xalate/ Hanford Soil System

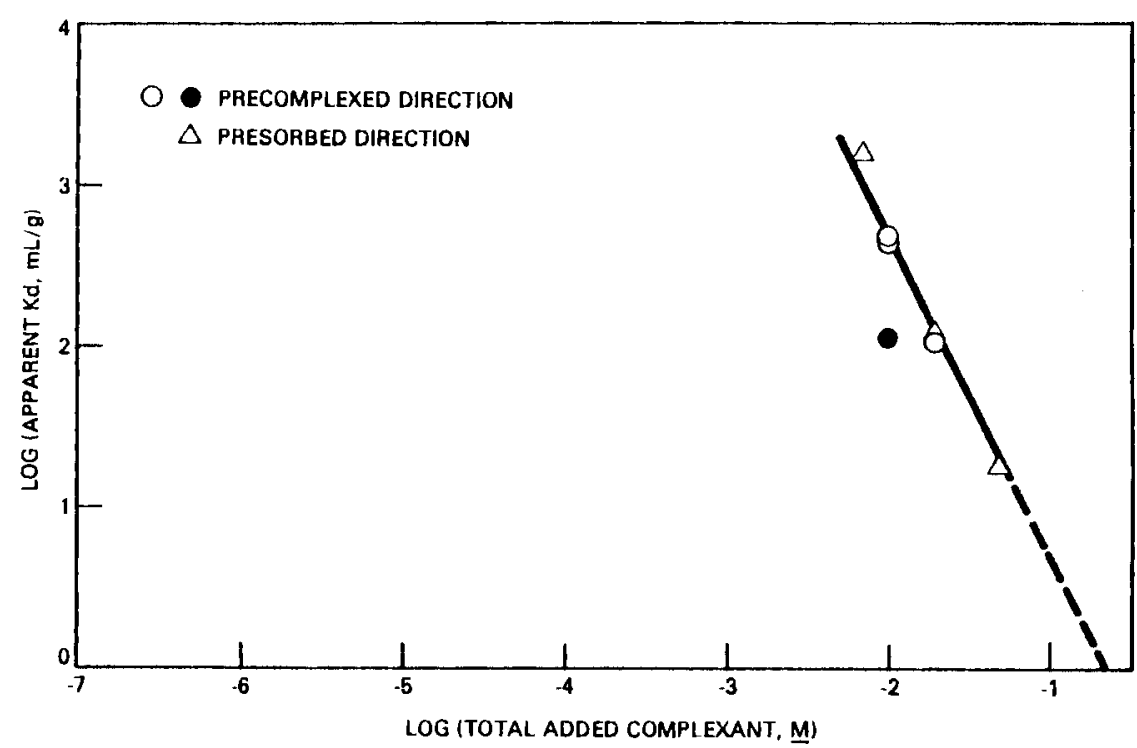

FIGURE 17. Equilibrium Data in Co(II)/Oxalate/ Hanford Soil System 
No data have been obtained for the cobalt/oxalate/Savannah River soil system.

\section{CITRATE}

Citrate is another organic complexing agent used in the nuclear industry that forms much weaker complexes with metal ions than does EDTA or DTPA.

\section{Nickel/Citrate}

Experiments in the $\mathrm{Ni} / \mathrm{Citrate/Hanford} \mathrm{soil} \mathrm{system} \mathrm{have} \mathrm{yielded} \mathrm{some}$ unexpected results. Typical data are shown in Figure 18 . In the precomplexed-type experiments, the rate of decrease in $\mathrm{Ni}$ concentration was faster at low citrate concentrations. Of greater interest, however, is the fact that in presorption-type experiments, in which the $\mathrm{Ni}$ is sorbed onto the soil before the complexant is added, the $\mathrm{Ni}$ concentration first rose rapidly and then decreased.

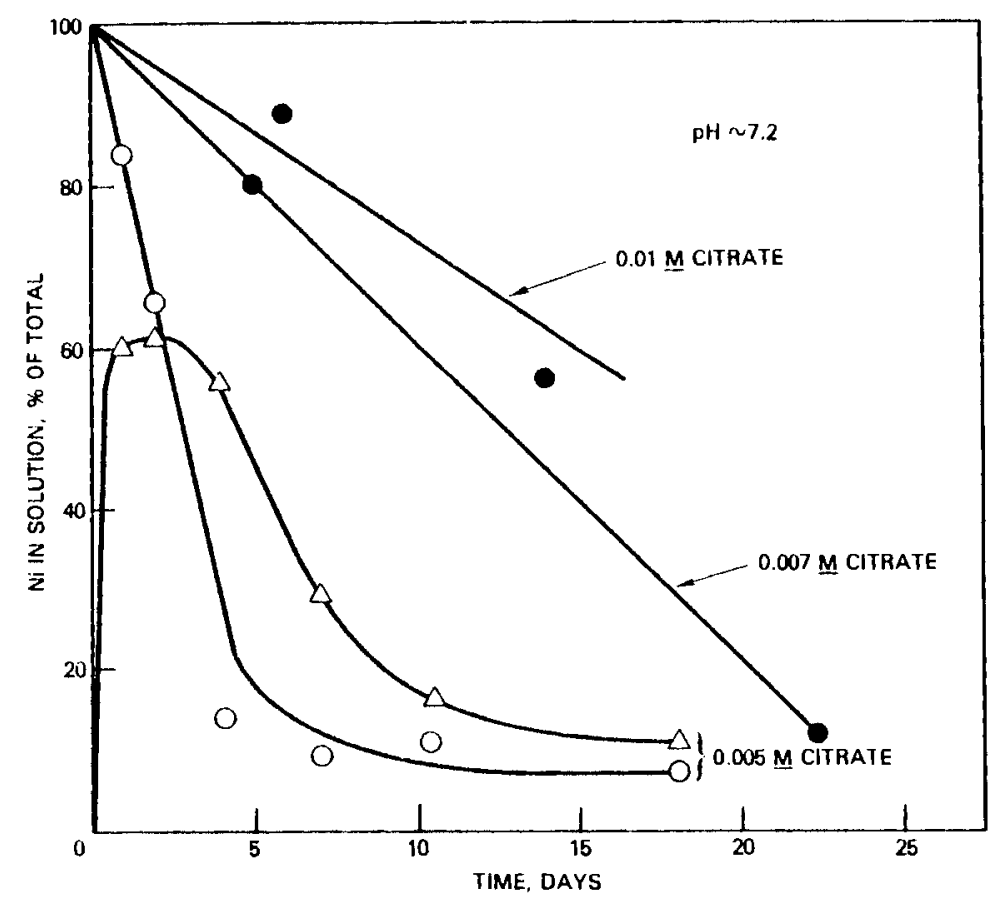

FIGURE 18. Ni/Citrate/Hanford Soil Data 
As mentioned earlier, this behavior is attributed to changing (decreasing) free citrate concentrations during the experiments. This could occur by decomposition of the citrate and/or by complexing of the citrate by metal ions that are slowly leaching from the soil. To test these hypotheses, a $0.005 \mathrm{M}$ citrate leachate of Hanford soil was analyzed for metal ions after 2 and 14 days. The concentration of calcium, which is the predominant metal ion in leachates of this soil, was $0.003 \mathrm{M}$ after 2 days and $0.00078 \mathrm{M}$ after 14 days. This drop in calcium concentration with time is just the reverse of that predicted by the hypothesis involving complexing by soil-derived metal ions, but is consistent with the hypothesis that citrate is decomposing. Additional work would be required to test this hypothesis, however.

Results with Savannah River soil in the Ni/citrate system are shown in Figure 19. As in the Hanford soil system, the change over time in the concentration of $\mathrm{Ni}$ indicates that the free complexant concentration is decreasing. This effect was especially pronounced in the experiment at the lower citrate concentration.

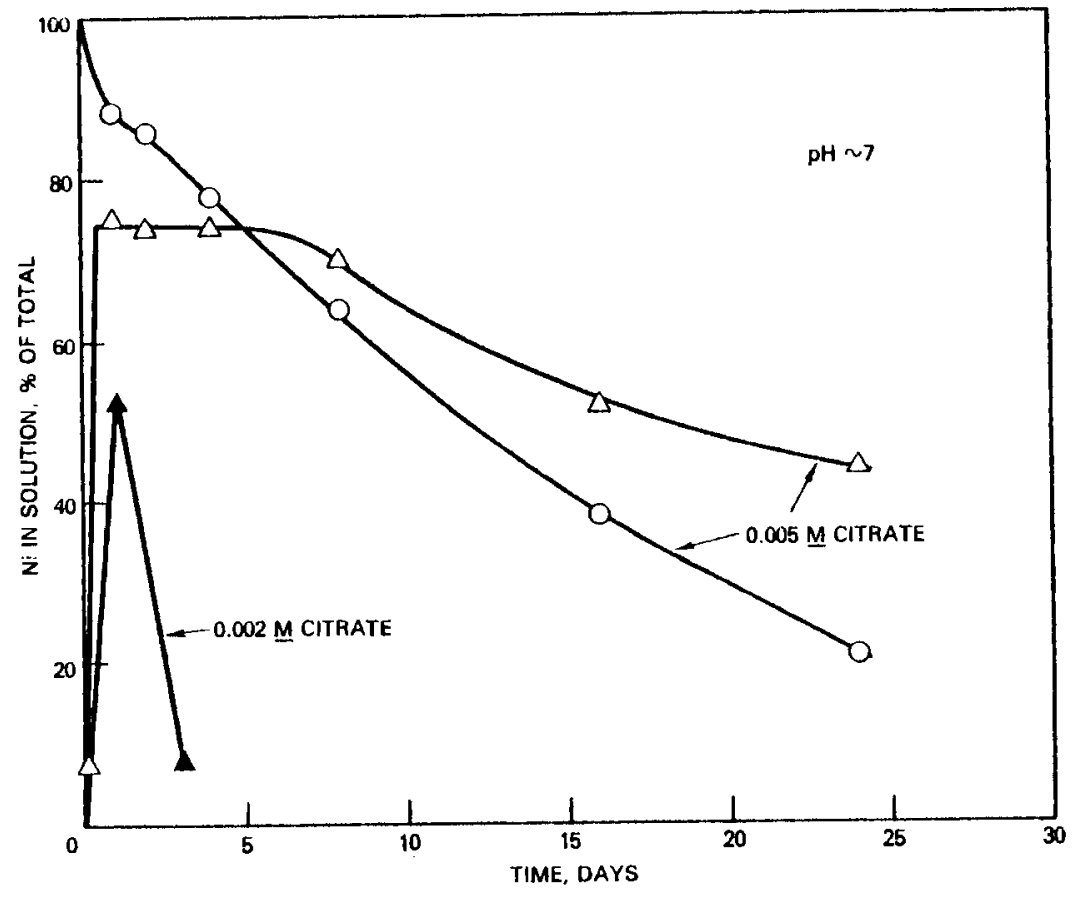

FIGURE 19. Ni/Citrate/Savannah River Soil Data 
While the majority of experimental work has involved measuring the distribution of radionuclides between soil and solution phases in the presence of various complexants, the leaching of metal ions froin the soils by complexants has also been studied. More data of this type will likely be required before the radionuclide behaviors can be understood well.

The data available are summarized in Table A.6. Some general observations follow:

- Calcium and Mg are the major elements in Hanford soil leached by the complexant solutions. The resultant concentration of $\mathrm{Ca}$ is generally equal to or greater than the concentration of complexant added. since Ca forms reasonably strong complexes with EDTA and DTPA, the concentration of free complexant must be very low in these solutions. It is the concentration of free complexant, not the concentration of total complexant, that will affect radionuclide behavior in these systems. The radionuclide distribution data were discussed earlier in terms of total complexant concentration, assuming that the free complexant concentration was a constant fraction of the total.

- With Savannah River soil and citrate leachant, less Ca and Mg and Inore $\mathrm{Al}$ and $\mathrm{Fe}$ were found in solution than in the corresponding Hanford soil experiment. 


\section{DISCUSSION}

Several of the points raised earlier warrant more general discussion. An overall comparison of some of the equilibrium results is al so desirable, even though only fragmentary information is available for many of the systems examined.

In Figure 20 are plotted Kd results as a function of total complexant concentration for the systems in which appropriate data are available. In some cases, error bars are included to represent the spread between the values obtained in precomplexed- and presorbed-type experiments at the time of writing; much smaller error bars are expected after longer time periods. The EU/EDTA data reported earlier (Swanson 1981) are plotted as well as the data contained in this report. There is quite a difference in results; some systems show a higher dependence of $K d$ on complexant concentration, and some complexants require a higher concentration to give an appreciable effect.

Data for many of these systems are still incomplete, but a few points appear to be valid. With Hanford soil, the trend agrees in most cases with that expected from the published values of the stability constants for the various complexes. That is, of the systems examined, the Co(II)/oxalate complex is the weakest and $\mathrm{Ni} / 0 x a l$ ate is next weakest; $\mathrm{Ni} / \mathrm{DTPA}$ is the strongest complex and Co(II)/DTPA is the next strongest; however, the fact that the Eu/EDTA complex is stronger than the Co(II)/EDTA complex is not reflected in these data. The data from Savannah River soil do not reflect the fact that the Ni/DTPA complex is stronger than the Ni/EDTA complex. In the Ni/DTPA system, where data are available for both soils, a higher concentration of DTPA is necessary to give a low Kd value with Savannah River soil than with Hanford soil.

The results shown in Figure 20 were obtained at a soil-to-solution ratio of about $0.033 \mathrm{~g} / \mathrm{mL}$. A variation of $\mathrm{Kd}$ with the soil-to-solution ratio has been observed in some systems; it is assumed that this is due to differences in the free complexant concentration (the quantity that actually governs the equilibria), as varying amounts of the complexant are complexed by metal ions 


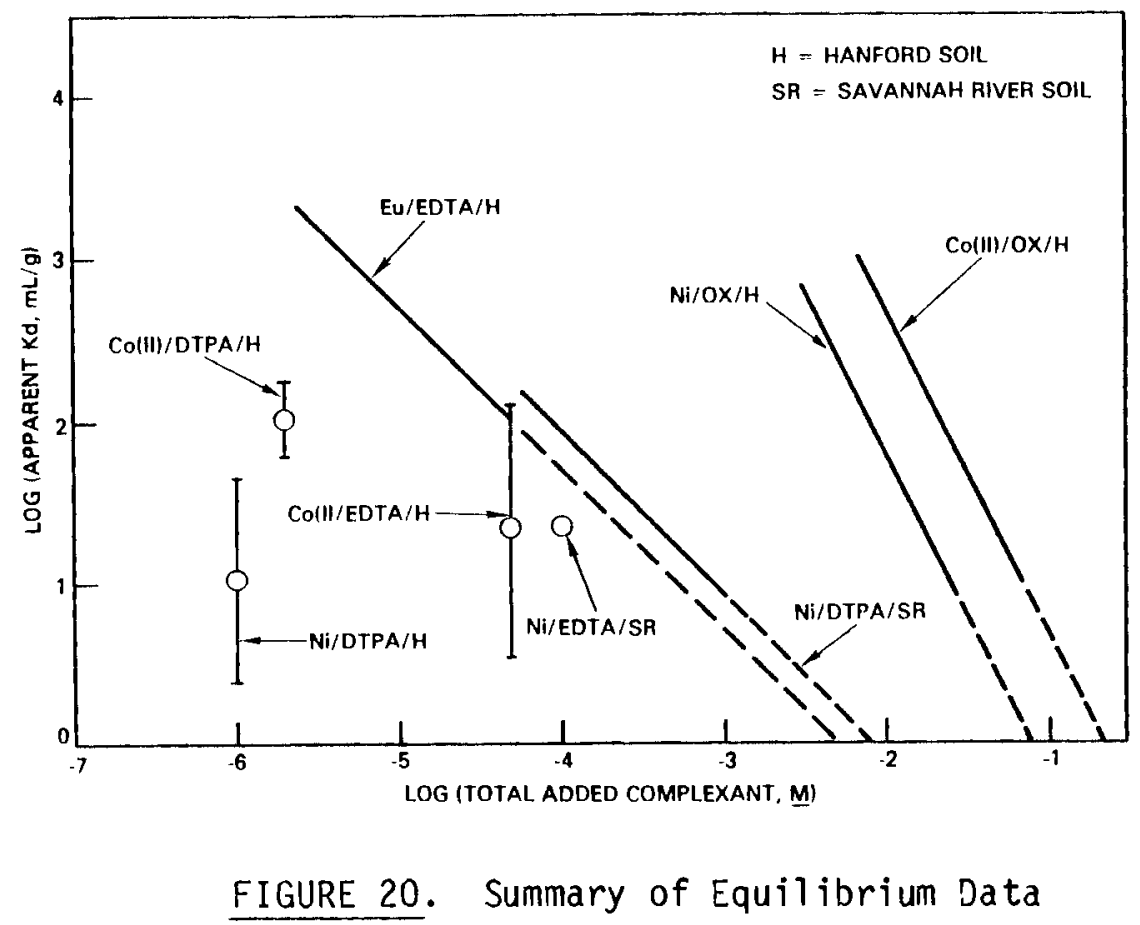

that leach from the soil. Thus, at a higher soil-to-solution ratio, a lower free complexant concentration would be obtained with a given total complexant concentration, and the lines in Figure 20 would sifift to the right la higher total complexant concentration would be required to produce a given change in the $k d$ value).

Also, it is important to note the complexant concentrations at which the $\mathrm{Kd}$ values are estimated to reach a value of $1 \mathrm{~mL} / \mathrm{g}$. While such a $\mathrm{Kd}$ value is really not very high, it is still sufficient to provide an appreciable retardation of the radionuclide in a groundwater system. The Kd value affects the radionuclide retardation factor, which is the ratio of the rate of water movement to the rate of radionuclide movement, according to the equation (Relyea et al. 1980):

$$
\text { Retardation Factor }=1+\frac{(\text { bulk density })(k d)}{\text { (effective porosity) }}
$$

If the bulk density is $2 \mathrm{~g} / \mathrm{cm}^{3}$ and the effective porosity is 0.2 , values in the range of typical ground water systems, a $\mathrm{Kd}$ value of $1 \mathrm{~mL} / \mathrm{g}$ gives a 
retardation factor of 11 . That is, the radionuclide would move through the soil 11 times more slowly than the water. Similarly, a $\mathrm{Kd}$ value of $10 \mathrm{~mL} / \mathrm{g}$ would give radionuclide movement 100 times slower than the groundwater movement for these conditions.

It can be seen in Figure 20 that the complexant concentrations required to give a $K d$ value as low as 1 are quite high for several systems. Thus, unless very high complexant concentrations are maintained in these systems, the mobility of these radionuclides in systems where equilibrium is obtained rapidly would not be high unless groundwater flows were very high. However, if groundwater flows are high, there may be appreciable dilution of the complexant, which would result in increased $k d$ values and thus increase the retardation factor. It is thus thought to be relatively unlikely that pronounced mobility of $\mathrm{Ni}$ and $\mathrm{Co}$ would occur in several of these complexant/soil systems in which equilibrium is obtained rapidly.

However, the systems that reach equilibrium slowly do afford the possibility of appreciable organic complexant-caused movement of $\mathrm{Ni}$ or $\mathrm{Co}$. In such cases, data such as those presented in Figure 20 are of lesser importance; what is important are the rates of complex dissociation and the rate at which the water moves through the soil, since the associated coinplexes will move as fast as the water.

The data obtained with the Hanford and Savannah River soils provide examples of different mechanisins for limiting the migration of radionuclides fron waste disposal sites. With the Hanford soil/groundwater system, where the Ni-EDTA complex dissociates very slowly and the $\mathrm{Ni}$ migrates through the soil at the same rate as the groundwater, the rate of migration of precomplexed $\mathrm{Ni}$ from a disposal site would still be low because the low rainfall rate gives a low rate of water migration. With the Savannah River soil/groundwater system, where a relatively high rainfall rate could give a high rate of water migration through the soil, the $\mathrm{Ni}-$ EDTA complex dissociates more rapidly and the uncomplexed $\mathrm{Ni}$ can then be sorbed by the soil. Thus little of the precomplexed Ni may migrate at the same rate as the water.

Another important factor in the systems that reach equilibrium slowly is whether the radionuclide is precomplexed before it is exposed to the soil. In the slow-equilibrating systems, this factor has a tremendous effect on the extent of radionuclide migration to be expected for a given distance of water 
migration. While the precomplexed radionuclide may migrate at the same rate as the ground water if the rate of complex dissociation is sufficiently slow; if the radionuclide is sorbed by the soil before it is exposed to the complexant, it may not travel far, even if the same quantity of complexant is present. This is because of slow desorption rates, especially at low complexant concentrations.

Another factor of importance to the rate of desorption of a presorbed radionuclide may be the length of time the radionuclide has been sorbed before it is exposed to the complexant. This has been observed in two radionuclide/complexant systems with Savannah River soil but has not yet been examined with Hanford soil.

A factor that would tend to reduce the likelihood of serious complexantcaused movement of radionuclides is that of complexant decomposition or degradation, which results in higher radionuclide Kd values as the free complexant concentration decreases. Such decomposition appears to have occurred in the citrate experiments discussed earlier. The environinental chemistry of several complexants has recently been summarized by Means and Alexander (1981). Little quantitative data are available on the rates at which such reactions occur, but such decomposition or degradation would tend to reduce the extent of complexant-caused movement of radionuclides, at least in systeins that reach equilibrium rapidly. The effect of such decomposition on slowly equilibrating systems is not known; depending on what factors control the rate of complex dissociation, complexant decomposition may not have a significant effect.

Several factors discussed here point to a conclusion regarding the effect of certain organic complexants on radionuclide mobility. The presence of oxalate or citrate in low-level waste would be much less likely to cause radionuclide mobility problems than would EDTA or DTPA. This is not only because oxalate and citrate form weaker complexes than do EDTA and DTPA, but also because oxalate and citrate do not form kinetically-inert complexes with $\mathrm{Co}_{\text {and }} \mathrm{Ni}$, as do EDTA and DTPA under some conditions. Al so, the decomposition rate of citrate appears to be quite rapid.

Perhaps this conclusion regarding the relative desirabilities of having the different complexants present in low-level waste could affect decisions regarding the degree of treatinent required for wastes before they can be 
disposed of. Such decisions could, in turn, aid in determining which complexants are used in the nuclear industry. Such "trade-off" considerations are beyond the scope of this program, however. 


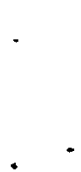




\section{PROCEDURES FORMAT}

The procedures format developed previously (Swanson 1981) has been generally followed in the current work, but one aspect has been found to be more useful than was previously realized. That is to initially perform simultaneous experiments at the same complexant concentration from both the precomplexed and presorbed directions. This has allowed earlier recognition of problems such as those observed in several of the systems, where the concentration of free complexant appears to change with time. In doing presorption-type experiments, the effect of the length of the presorption time period should also be examined; this has recently been found to be important in some cases.

Another modification of the previously recommended procedure would be to use shorter time intervals between measurements until it is determined that the kinetics are slow in the systen under investigation. 




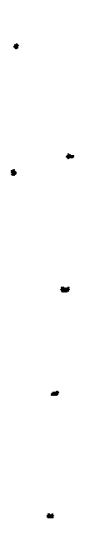




\section{REFERENCES}

Cleveland, J. M. and T. F. Rees. 1981. "Characterization of Plutonium in Maxey Flats Radioactive Trench Leachates." Science 212:1506-1509.

Kirkham, R. R. and T. L. Jones. 1982. "Field Tracer Study." In Nuclear Waste Management Semiannual Progress Report, October 1981 through March 1982, compiled by T. D. Chikalla and J. A. Powell. PNL-4250, Pacific Northwest Laboratory, Richland, Washington.

Means, 1. L. and C. A. Al exander. 1981. "The Environmental Biogeochemistry of Chelating Agents and Recommendations for the Disposal of Chelated Radioactive Wastes." Nuclear and Chemical Waste Management 2:183-196.

Relyea, J.F., R. J. Serne, and D. Rai. 1980. Methods for Determining Radionuclide Retardation Factors: Status Report. PNL-3349, Pacific Northwest Laboratory, Richland, Washington.

Swanson, J. L. 1981. Effect of Organic Complexants on the Mobility of LowLevel Waste Radionuclides in Soils: Status Report. PNL-3927, Pacific Northwest Laboratory, Richland, Washington. 


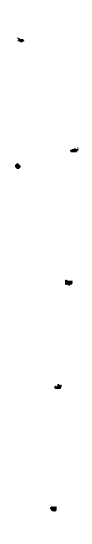




\section{ACKNOWLEDGMENTS}

The experiments were performed and the radionuclide distribution measurements were made by $A$. D. Peoples. The ICP analyses were performed under the direction of F. T. Hara and A. W. Lautensleger. Soil from the Savannah River site was obtained through the courtesy of J. R. Wiley of Savannah River Laboratory.

The report was typed by L. D. Maki and edited by S. E. King. 


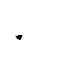




\section{APPENDIX}

SUPPLEMENTAL DATA ON RADIONUCLIDE SORRPTION AND

THE LEACHING OF METAL IONS FROM SOILS 
TABLE A.1. Sorption of $\mathrm{Ni}$ by Hanford Soil in the Absence of Complexants

\begin{tabular}{|c|c|c|c|c|c|c|}
\hline Tube & $\begin{array}{l}\text { Initial } \\
\mathrm{Ni}, \mathrm{M} \\
\end{array}$ & $\begin{array}{c}\mathrm{g} \text { Soill/ } \\
\mathrm{mL} \text { Solution }\end{array}$ & $\begin{array}{l}\text { Time, } \\
\text { Days }\end{array}$ & $\begin{array}{l}\mathrm{Ni} \text { in } \\
\text { Soln., \% }\end{array}$ & $\begin{array}{c}\text { Apparent Kd, } \\
\mathrm{mL} / \mathrm{g}\end{array}$ & $\mathrm{pH}$ \\
\hline \multirow[t]{2}{*}{409} & \multirow[t]{2}{*}{$2 \times 10^{-7}$} & \multirow[t]{2}{*}{0.033} & 4 & $2.2^{(a)}$ & 1,300 & 9.1 \\
\hline & & & 11 & $2.2^{(a)}$ & 1,300 & 8.8 \\
\hline 435 & $1 \times 10-7$ & 0.033 & 7 & $2.1^{(a, b)}$ & 1,400 & 8.8 \\
\hline \multirow[t]{3}{*}{426} & \multirow[t]{3}{*}{$2 \times 10^{-8}$} & \multirow[t]{3}{*}{0.033} & 6 & $2.3^{(a)}$ & 1,300 & \\
\hline & & & 13 & $3.9^{(a)}$ & 740 & 8.9 \\
\hline & & & 19 & $2.9^{(a)}$ & 1,000 & 8.8 \\
\hline 534 & $5 \times 10^{-9}$ & 0.033 & 3 & $2.6^{(c)}$ & 1,100 & 9.3 \\
\hline \multirow[t]{6}{*}{553} & \multirow[t]{6}{*}{$4 \times 10^{-9}$} & \multirow[t]{6}{*}{0.033} & 1 & $7.9^{(d)}$ & & \multirow[t]{2}{*}{9.5} \\
\hline & & & 2 & $7.9^{(d)}$ & & \\
\hline & & & \multirow[t]{2}{*}{3} & $2.2^{(c)}$ & 1,300 & 9.3 \\
\hline & & & & $7.2^{(d)}$ & & 9.3 \\
\hline & & & \multirow[t]{2}{*}{6} & $9.1^{(d)}$ & & \\
\hline & & & & $2.1^{(c)}$ & 1,400 & 8.9 \\
\hline \multirow[t]{2}{*}{427} & \multirow[t]{2}{*}{$9 \times 10^{-8}$} & \multirow[t]{2}{*}{0.010} & 6 & $4.7^{(a)}$ & 2,000 & \\
\hline & & & 13 & $5.2^{(\mathrm{a})}$ & 1,800 & 9.1 \\
\hline \multirow[t]{2}{*}{ NS-4 } & \multirow[t]{2}{*}{$8 \times 10^{-8}$} & \multirow[t]{2}{*}{0.0034} & 14 & $3.2^{(a)}$ & 8,800 & 8.0 \\
\hline & & & 42 & $2.3^{(a)}$ & 13,000 & 8.1 \\
\hline 441 & $2 \times 10^{-8}$ & 0.0033 & 7 & $3.6^{(a)}$ & 8,000 & 9.5 \\
\hline 425 & $1 \times 10^{-7}$ & 0.033 & 6 & $24(a, e)$ & 100 & 6.3 \\
\hline
\end{tabular}

(a) $0.1 \mu \mathrm{m}$ polycarbonate filter.

(b) Initial solution was $0.01 \mathrm{M} \mathrm{NaCl}$.

(c) $0.015 \mu \mathrm{m}$ polycarbonate filter.

(d) Centrifuged only.

(e) Initial solution was $0.01 \mathrm{M} \mathrm{HCl}$. 
TABLE A.2. Sorption of $\mathrm{Ni}$ by Savannah River Soil in the Absence of Complexants

\begin{tabular}{|c|c|c|c|c|c|}
\hline Tube & $\begin{array}{c}\text { Initial } \\
\mathrm{Ni}, \mathrm{M} \\
\end{array}$ & $\begin{array}{l}\text { Time, } \\
\text { Days }\end{array}$ & $\begin{array}{l}\mathrm{Ni} \text { in } \\
\text { Soln., \% }\end{array}$ & $\begin{array}{r}\text { Apparent } \mathrm{Kd},(\mathrm{a}) \\
\mathrm{mL} / \mathrm{g}\end{array}$ & $\mathrm{pH}$ \\
\hline \multirow[t]{3}{*}{447} & $2 \times 10^{-8}$ & 4 & $6.3^{(b)}$ & 440 & 6.0 \\
\hline & & 12 & $1.6^{(b)}$ & 1,800 & 6.1 \\
\hline & & 26 & $0.8^{(b)}$ & 3,800 & 6.2 \\
\hline \multirow[t]{2}{*}{547} & $5 \times 10^{-9}$ & 1 & $21^{(c)}$ & 110 & \\
\hline & & & $21^{(d)}$ & 110 & \\
\hline \multirow[t]{5}{*}{498} & $5 \times 10^{-9}$ & 1 & $15^{(c)}$ & 180 & 7.4 (?) \\
\hline & & & $17^{(d)}$ & 150 & \\
\hline & & 5 & $2.5^{(d)}$ & 1,200 & \\
\hline & & 32 & $0.8^{(c)}$ & 3,500 & 6.1 \\
\hline & & & $0.4^{(d)}$ & 7,500 & \\
\hline \multirow[t]{2}{*}{548} & $5 \times 10^{-9}$ & 8 & $3.8^{(c)}$ & 760 & \\
\hline & & & $4.0^{(d)}$ & 720 & \\
\hline \multirow[t]{6}{*}{552} & $4 \times 10^{-9}$ & 1 & $16^{(d)}$ & 150 & 6.2 \\
\hline & & 2 & $8.7^{(c)}$ & 310 & \\
\hline & & & $11^{(d)}$ & 230 & 6.1 \\
\hline & & 3 & $10^{(d)}$ & 260 & 6.0 \\
\hline & & 6 & $4.5^{(c)}$ & 640 & 5.9 \\
\hline & & & $6.0^{(a)}$ & 470 & \\
\hline
\end{tabular}

(a) Using 150- to $500-\mu \mathrm{m}$ soil. Soil-to-solution ratio $=0.033 \mathrm{~g} / \mathrm{mL}$.

(b) $0.1 \mu \mathrm{m}$ polycarbonate filter.

(c) $0.015 \mu \mathrm{ml}$ polycarbonate filter.

(a) Centrifuged only. 
TABLE A.3. Ni/DTPA Savannah River Soil Data

\begin{tabular}{|c|c|c|c|c|c|c|}
\hline Tube & $\begin{array}{l}\text { Added Conce } \\
\text { DTPA, M } \\
\end{array}$ & $\frac{\text { trations }}{\mathrm{Ni}, \mathrm{M}}$ & $\begin{array}{l}\text { Time, } \\
\text { Days } \\
\end{array}$ & $\begin{array}{l}\mathrm{Ni} \text { in } \\
\text { Soln., \% }\end{array}$ & $\begin{array}{l}\text { Apparent } \mathrm{Kd},(\mathrm{a}) \\
\mathrm{mL} / \mathrm{g}\end{array}$ & $\mathrm{pH}$ \\
\hline \multicolumn{7}{|c|}{ Precomplexed Direction } \\
\hline \multirow[t]{2}{*}{513} & $5.0 \times 10^{-7}$ & $5 \times 10^{-9}$ & 3 & 4.0 & 720 & 6.8 \\
\hline & & & 7 & 4.0 & 720 & 6.0 \\
\hline \multirow[t]{2}{*}{514} & $5.0 \times 10^{-6}$ & $3 \times 10^{-9}$ & 3 & 4.9 & 580 & 6.1 \\
\hline & & & 7 & 4.6 & 620 & 6.0 \\
\hline \multirow[t]{5}{*}{521} & $5.5 \times 10^{-5}$ & $4 \times 10^{-9}$ & 3 & 27 & & 6.0 \\
\hline & & & 6 & 16 & 160 & \\
\hline & & & 10 & 16 & 160 & 5.5 \\
\hline & & & 18 & 16 & 160 & \\
\hline & & & 26 & 20 & 120 & 6.0 \\
\hline \multirow[t]{4}{*}{522} & $5.0 \times 10^{-4}$ & $4 \times 10^{-9}$ & 3 & 71 & 12 & 4.0 \\
\hline & & & 7 & 73 & 11 & 4.0 \\
\hline & & & 15 & 55 & 25 & \\
\hline & & & 23 & 47 & 34 & \\
\hline \multirow[t]{3}{*}{555} & $1.0 \times 10^{-3}$ & $5 \times 10^{-9}$ & 3 & 96 & 1 & 3.0 \\
\hline & & & 7 & 79 & 8 & \\
\hline & & & 14 & 79 & 8 & 3.8 \\
\hline \multicolumn{7}{|c|}{ Presorbed Direction } \\
\hline \multirow[t]{2}{*}{$514^{(c)}$} & $1.6 \times 10^{-5}$ & $3 \times 10^{-9}$ & 3 & 13 & 200 & \\
\hline & & & 7 & 13 & 200 & 5.9 \\
\hline \multirow[t]{2}{*}{$513^{(c)}$} & $5.2 \times 10^{-5}$ & $5 \times 10^{-9}$ & 3 & 21 & 110 & \\
\hline & & & 10 & 23 & 100 & 5.9 \\
\hline \multirow[t]{3}{*}{554} & $1.0 \times 10^{-3}$ & $5 \times 10^{-9}$ & 3 & 57 & 23 & 3.3 \\
\hline & & & 7 & 64 & 17 & \\
\hline & & & 14 & 64 & 17 & 4.1 \\
\hline
\end{tabular}

\footnotetext{
(a) Using $150-$ to $500-\mu \mathrm{m}$ soil. Soil-to-solution ratio $=0.033 \mathrm{~g} / \mathrm{mL}$.

(b) Ni stood in $>5 \times 10^{-5}$ M DTPA for 2 days before the solution was diluted and soil was added.

(c) More DTPA was added to sorption experiments after apparent equilibrium was reached.
} 
TABLE A.4. Ni/0xalate/Hanford Soil Data

Added

Tube $\frac{\text { Concentrations, } M}{\left(\mathrm{NH}_{4}\right)_{2} \mathrm{C}_{2}-{ }_{4}}$

g Soill mL Solution Days Soln., \%

Apparent Kd, Precomplexed Direction

\begin{tabular}{lll}
\hline 440 & 0.0020 & $2 \times 10^{-8}$ \\
429 & 0.0020 & $2 \times 10^{-8}$
\end{tabular}

$$
0.010^{(a)}
$$

7

25

$0.033^{(a)}$

15

$468 \quad 0.0030 \quad 6 \times 10^{-9}$

$0.033^{(b)}$

7

10

14

3.6

31
$438 \quad 0.0040 \quad 4 \times 10^{-8}$

$483 \quad 0.0080 \quad 2 \times 10^{-9}$

$$
0.033^{(a)}
$$

1

4

10

$467 \quad 0.0080 \quad 6 \times 10^{-9}$

$0.033^{(b)}$

5

22

$467 \quad 0.0080$

$473 \quad 0.0080 \quad 6 \times 10^{-9}$

$0.033^{(b)}$

3.6

$\mathrm{mL} / \mathrm{g}$

$\underline{\mathrm{pH}}$ 
TABLE A.4. (contd)

Added

Tube $\frac{\text { Concentrations, } M}{\left(\mathrm{NH}_{4}-_{2}-_{2}-{ }_{4}\right.}$

g Soill Time, $\mathrm{Ni}$ in Apparent $\mathrm{Kd}$,

$471 \quad 0.015 \quad 2 \times 10^{-9}$

mL Solution Days Soln., $\%$

\begin{tabular}{ccc}
$\mathrm{mL} / \mathrm{g}$ & $\mathrm{pH}$ \\
\hline 31 & & 8.6 \\
29 & & 8.5 \\
26 & & 8.6 \\
33 & & 8.5 \\
27 & &
\end{tabular}

466

0.015

$6 \times 10^{-9}$

$0.033^{(b)}$

1

49

51

$0.033^{(b)}$

4

1

54

48

8.5

10

52

19

$464 \quad 0.015 \quad 2 \times 10^{-8}$

$0.033^{(b)}$

25

62

14

8.4

4

15

8.4

$11 \quad 70$

13

8.4

$499 \quad 0.015 \quad 3 \times 10^{-8}$

$0.033^{(b)}$

19

73

12

8.2

4

48

33

8.4

$465 \quad 0.028 \quad 2 \times 10^{-8}$

$0.033^{(b)}$

11

47

34

$472 \quad 0.030 \quad 6 \times 10^{-9}$

$0.033^{(b)}$

85

8.2

84

8.2

75

8.3

76

8.3

25

80

7.2

Presorbed Direction

$479 \frac{015}{0.010^{-9}}$

$0.033^{(b)}$

136

53

8.5

3

40

46

8.5

6

42

41

$480 \quad 0.030 \quad 5 \times 10^{-9}$

$\begin{array}{rrr}0.033^{(b)} & 10 & 45 \\ & 1 & 78 \\ & 3 & 67 \\ & 6 & 73 \\ & 13 & 76\end{array}$

37

9

8.3

15

8.3

11

9

Second Contact

$499 \mathrm{~b} \quad 0.015(c) \quad 1 \times 10-8(c)$

$0.033^{(b)}$

3

40

45

8.8

36

(a) Using 75- to $150-\mu \mathrm{m}$ soil.

(b) Using 150- to 500- $\mathrm{mm}$ soil.

(c) The equilibrated solution from the first contact.

A. 5 
TABLE A.5. Co(II) 0xalate/Hanford Soil Data

Added Concentrations, Tube $\frac{\left(\mathrm{NH}_{4}\right)_{2} \mathrm{C}_{2} \mathrm{O}_{4}-\mathrm{CO}}{-}$ g Soill/(a) mL Solution Days Soln.,\%
Apparent Kd, $\mathrm{mL} / \mathrm{g} \quad \mathrm{pH}$

Precomplexed Direction

\begin{tabular}{|c|c|c|c|c|c|c|c|}
\hline \multirow[t]{2}{*}{475} & 0.010 & $1 \times 10^{-7}$ & 0.0035 & 8 & 71 & 120 & 7.4 \\
\hline & & & & 18 & 72 & 110 & \\
\hline \multirow[t]{2}{*}{474} & 0.010 & $1 \times 10^{-7}$ & 0.035 & 8 & 5.6 & 480 & 8.4 \\
\hline & & & & 18 & 5.2 & 520 & \\
\hline \multirow[t]{2}{*}{476} & 0.010 & $1 \times 10^{-6}$ & 0.035 & 8 & 6.4 & 510 & 4 \\
\hline & & & & 18 & 5.8 & 460 & \\
\hline \multirow[t]{3}{*}{460} & 0.020 & $1 \times 10^{-6}$ & 0.033 & 4 & 23 & 100 & .3 \\
\hline & & & & 7 & 21 & 110 & \\
\hline & & & & 14 & 20 & 120 & \\
\hline \multicolumn{8}{|c|}{ Presorbed Direction } \\
\hline \multirow[t]{3}{*}{$\overline{461}$} & 0.0070 & $1 \times 10^{-6}$ & 0.033 & 4 & 1.8 & 1,600 & .8 \\
\hline & & & & 7 & 1.8 & 1,600 & \\
\hline & & & & 14 & 1.8 & 1,600 & \\
\hline \multirow[t]{3}{*}{459} & 0.020 & $1 \times 10^{-6}$ & 0.033 & 4 & 18 & 140 & .2 \\
\hline & & & & 7 & 19 & 130 & \\
\hline & & & & 14 & 20 & 130 & \\
\hline \multirow[t]{3}{*}{462} & 0.050 & $1 \times 10^{-6}$ & 0.033 & 4 & 60 & 20 & 8.0 \\
\hline & & & & 7 & 63 & 18 & \\
\hline & & & & 14 & 64 & 17 & \\
\hline
\end{tabular}

(a) Using 150- to 500- $\mu \mathrm{m}$ soil. 
TABLE A.6. Metal Ions Leached From Soils

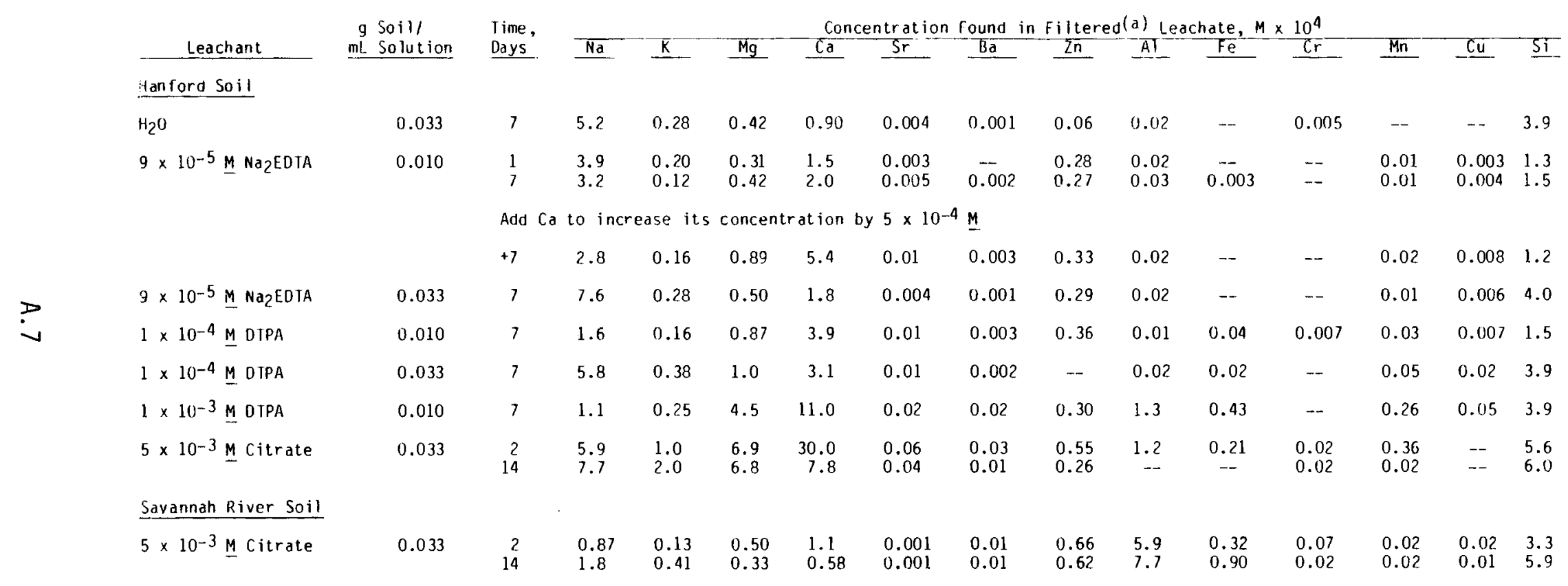

(a) Using 2-nm membrane filter cores. 
- 
No. of

Copies

OFFSITE

\section{DOE Technical Information Center}

D. H. Al exander

Office of Research

Nuclear Regulatory Commission

Washington, D. C. 20555

R. E. Cunningham

Office of Nuclear Safety Materials and Safeguards

Room 562

Nuclear Regulatory Commission

7915 Eastern Avenue

Silver Springs, MD 20910

J. B. Martin

Division of Waste Management

Nuclear Regulatory Commission

Washington, DC 20555

W. E. Mott

DOE Division of Environmental

Control Technology

Washington, DC

G. Dertel, NE-320, GTN

DOE Office of Nuclear Waste

Management

Washington. DC 20545

D. B. Rohrer

Division of Waste Management Nuclear Regulatory Commission Washington, DC 20555

R. D. Smith

Division of Waste Managenent

Nuclear Regulatory Commission

Washington, DC 20555

R. J. Starmer

Low-Level Waste Licensing

Nuclear Regulatory Commission

M/S 623 SS

Washington, DC 20555
No. of

Copies

OFFSITE

J. D. Dieckhoner, NE-321, GTN DOE Office of Nuclear Waste Management

Washington, DC 20545

D. J. MCGoff, NE-320, GTN

DOE Office of Nuclear Waste Management

Washington, DC 20545

C. A. Heath, NE-330, GTN

DOE Office of Nuclear Waste Management

Washington, DC 20545

S. A. Mann

Chicago Operations and Region office

Argonne, IL 60439

J. D. Neff

DOE Columbus Program Office

$505 \mathrm{King}$ Avenue

Columbus, $\mathrm{OH} 43201$

M. J. Barainca

DOE Idaho Operations office

505 Second Street

Idaho Falls, ID 83401

J. P. Hamric

DOE Idaho Operations office

505 Second Street

Idaho Fal1s, ID 83401

J. B. Whitsett

DOE Idaho Operations office

505 Second Street

Idaho Fa11s, ID 83401

2 S. W. Ahrends

DOE Oak Ridge Operations office P. D. Box E

Oak Ridge, TN 37830 
No. of

Copies

OFFSITE

D. E. Large

DOE Oak Ridge Operations Office

P. D. Box E

Oak Ridge, TN 37830

W. B. Wilson

DOE Savannah River Operations Office

P. 0. Box A

Aiken, SC 29801

T. B. Hindman

DDE Savannah River Operations Office

P. 0. Box A

Aiken, SC 29801

M. C. Kirkland

DOE Savannah River Operations Office

P. D. Box A

Aiken, SC 29801

2 R. Y. Lowrey

DOE Albuquerque Operations Office

P.0. Box 5400

Albuquerque, NM 87185

A. L. Taboas

DOE Albuquerque Operations Office

P. D. Box 5400

A1buquerque, NM 87185

S. G. Harbinson

DOE San Francisco Operations Office

1333 Broadway

Oakland, CA 94612

2 Environmental Protection Agency

Technological Assessment Division (AW-559)

Office of Radiation Programs

Washington, DC 20460
No. of

Copies

OFFSITE

J. H. Kittle

Argonne National Laboratory

9700 South Cass Avenue

Argonne, IL 60540

Beverly Rawles

Battelle Memorial Institute

505 King Avenue

Columbus, OH 43201

Research Library

Battelle Memorial Institute

505 King Avenue

Columbus, $\mathrm{OH} 43201$

P. Columbo

Brookhaven National Laboratory

Upton, NY 11973

G. B. Levin

EG\&G Idaho

P. 0. Box 1625

Idaho Falls, ID 83415

M. D. McCormack

EG\&G Idaho

P. 0. Box 1625

Idaho Falls, ID 83415

Robert Williams

Electric Power Research Institute

3412 Hillview Avenue

Palo Al to, CA 94304

G. L. De Poorter

Los Al amos National Laboratory

P.0. Box 1663

Los Al amos, NM 87545

William F. Holcomb

National Institute of Health

Radiation Safety Branch

Building 21

Bethesda, MD 20205 
No. of

Copies

OFFSITE

N. H. Cutshall

Oak Ridge National Laboratory

P. 0. Box $X$

Oak Ridge, TN 37830

A. L. Lotts

Oak Ridge National Laboratory

P. O. Box X

Oak Ridge, TN 37830

L. J. Mezga

Dak Ridge National Labortory

P. D. Box $X$

Oak Ridge, TN 378309

Central Research Library

Dak Ridge National Laboratory

P. 0. Box X

Oak Ridge, TN 37830

J. Wiley

Savannah River Laboratory

P. 0. Box A

Aiken, SC 29801

ONSITE

5 DOE Richland Operations office

E. A. Bracken

P. A. Craig (2)

R. D. Gerton

H. E. Ransorn

5 Rockwell Hanford Operations

J. H. Roecker

R. C. Routson

R. D. Wodrich (3)

UNC United Nuclear Industries

F. H. Bouse, Document Control

Westinghouse Hanford Company
No. of

Copies

ONSITE

57 Pacific Northwest Laboratory

L. L. Ames

L. A. Bray

R. L. Brodzinski

L. L. Burger

T. D. Chikalla

J. A. Franz

T. R. Garl and

G. W. Gee

J. H. Jarrett

E. A. Jenne

T. L. Jones

S. E. King (3)

L. .]. Kirby

M. R. Kreiter

J. M. Latkovich

J. L. MCEl roy

L. D. Maki

R. E. Nightingale

A. D. Peoples

R. W. Perkins

A. M. Platt

D. Rai

J. V. Robinson

R. J. Serne

S. L. Stein

J. L. Swanson (20)

A. P. Toste

H. H. Van Tuyl

E. J. Wheelwright

Technical Information (5)

Publishing Coordination (2)

R. E. Lerch 


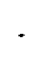

